\title{
KEBIJAKAN HUKUM PIDANA DALAM TINDAK PIDANA CYBER DI BIDANG PORNOGRAFI ANAK (CYBER CHILD PORNOGRAPHY) DI INDONESIA Syahriman Jayadi, SH
}

\begin{abstract}
Child pornography (Pornografi anak) di Indonesia saat ini semakin marak dan semakin mengkhawatirkan. Kemajuan informasi dan teknologi yang demikian pesat memberi manfaat yang cukup besar. Tetapi ternyata juga berdampak negatif luar biasa. Media pornografi anak semakin mudah untuk diakses melalui media elektronik dan cetak. Begitu mudahnya setiap anak untuk melihat materi pornografi melalui internet, handphone, buku bacaan dan VCD. Kemudahan mengakses materi pornografi dapat mencontoh aktifitas seksual sesuai dengan adegan yang ditontonnya. Inilah yang menyebabkan kekerasan seksual terhadap anak yang dilakukan oleh sesamanya.
\end{abstract}

\section{PENDAHULUAN}

\section{A. Latar Belakang}

Salah satu masalah cyber crime yang juga sangat meresahkan dan mendapat perhatian berbagai kalangan, adalah masalah cyber crime di bidang kesusilaan. Semakin maraknya pelanggaran kesusilaan di dunia cyber ini, terlihat dengan munculnya berbagai istilah seperti : cyber pornography (khususnya child pornography), online pornography, cyber sex, cyber sexer, cyber lover, cyber romance, cyber affair, online romance, sex online, cybersex addicts, cyber sex offender. Khususnya masalah "cyber child pornography", dalam Konvensi Cybercrime Dewan Eropa 2001 di Budapest (yang juga ikut ditanda-tangani oleh Negara-negara di luar Eropa, a.l. Jepang, Kanada, USA, Afrika Selatan), sudah disepakati untuk dikriminalisasi. Sebelum Konvensi Dewan Eropa ini, keprihatinan dunia terhadap masalah eksploitasi sex anak dan pornografi anak terlihat antara lain dengan diselenggarakannya :

1. The first World Congress Against Commercial Sexual Exploitation of Children, Stockholm, 27 - 31 August 1996, dan

2. International Conference on "Combatting Child Pornography on the Internet", Vienna, Hofburg, 29 September - 1 October 1999.

Di masa mendatang, pornografi di internet adalah bencana besar terhadap anak yang akan menghantui orang tua. Belum lagi semakin banyaknya bisnis 
warung internet yang dengan leluasa dijelajahi secara bebas oleh anak-anak. Sebuah kelompok hak anak melaporkan, jumlah website yang menyediakan pornografi anak-anak tahun lalu meningkat dengan $70 \%$. Didapatkan fakta yang mencengangkan lainnya bahwa pornografi masih menjadi konsumsi tertinggi bagi para pengakses internet. Ternyata didapatkan $12 \%$ situs di dunia ini mengandung pornografi. Setiap harinya 266 situs porno baru muncul dan diperkirakan kini ada 372 juta halaman website pornografi. Sedangkan $25 \%$ yang dicari melalui search engine adalah pornografi. Ternyata peminat pornografi internet demikian besar $35 \%$ dari data yang didapat dari internet adalah pornografi, setiap detiknya 28.258 pengguna internet melihat pornografi dan setiap detiknya \$ 89.00 dihabiskan untuk pornografi di internet. ${ }^{1}$

Undang-Undang No 11 tahun 2008 ini diharapkan dapat menanggulangi kejahatan-kejahatan yang sarana teknologi, informasi dan elekekrtonik (cyber crime), yang juga dapat menanggulangi tindak pidana cyber child pornoghrapy yang merupakan bagian dari salah satu jenis cyber crime tersebut.

Guna menghadapi perkembangan terhadap cyber child pornography

\footnotetext{
${ }^{1}$ Widodo Judarwanto 2 November 2008, Undangundang Pornografi Selamatkan Anak Indonesia. http://UU Pornografi selamatkan anak indonesia-wikiMu.mht

(pornografi anak di internet) dengan hukum pidana maka perlu kiranya dikaji lebih mendalam arti pentingnya kebijakan hukum pidana dalam menanggulangi masalah tersebut, baik untuk kondisi saat ini maupun di masa yang akan datang.

Kebijakan hukum pidana yang ditekankan dalam penanggulangan masalah cyber child pornografhy (pornografi anak di internet) terutama adalah kebijakan formulatif yaitu bagaimana formulasi perumusan suatu delik serta sanksi apa yang akan dikenakan terhadap pelanggarnya. Kebijakan formulatif adalah tahap yang paling strategis, selain tahap aplikatif atau penerapan rumusan peraturan perundang-undangan yang telah dibuat dan tahap eksekutif yang merupakan tahap pelaksanaan hukum pidana.

\section{B. Rumusan Masalah}

Bertolak dari latar belakang yang dikemukakan di atas, maka permasalahan pokok dalam penelitian ini adalah sebagai berikut:

1. Bagaimanakah Kebijakan formulasi hukum pidana dalam menanggulangi tindak pidana cyber child pornoghrapy di Indonesia saat ini?

2. Bagaimanakah Kebijakan formulasi hukum pidana dalam menanggulangi tindak pidana cyber child pornoghrapy di Indonesia di masa yang akan datang? 


\section{HASIL PENELITIAN DAN PEMBAHASAN}

\section{A. Kebijakan Formulasi Hukum Pidana Dalam Menanggulangi Tindak Pidana Cyber Child Pornoghrapy di Indonesia Saat Ini}

\section{Dalam UU Nomor 8 tahun 1992 tentang Perfilman}

a. Sistem perumusan tindak pidana dalam Undang-Undang Perfilman

Ketentuan pidana dalam Undangundang Nomor 8 tahun 1992 tentang Perfilman terdapat dalam Bab X Pasal 40 sampai dengan Pasal 42, adapun yang erat kaitannya dengan cyber child pornography

Berdasarkan ketentuan pasal-pasal tersebut di atas, maka dapat di identifikasikan perbuatan yang dilarang (unsur tindak pidana) pada tiap-tiap pasalnya sebagai berikut:

1) Pasal 40 sub a jo Pasal 33 ayat (6) dengan unsur tindak pidana: mengedarkan, mengekspor, mem pertunjukkan dan/atau menayangkan film dan/atau reklame film atau potongannya yang ditolak oleh lembaga sensor film, tidak untuk untuk kepentingan penelitian dan/atau penegakan hukum;

2) Pasal 40 sub b jo Pasal 33 ayat (6) dengan unsur tindak pidana: mengedarkan, mengekspor, mem pertunjukkan dan/atau menayangkan potongan film dan/atau suara tertentu yang ditolak oleh lembaga sensor film, tidak untuk kepentingan penelitian dan/atau penegakan hukum;

3) Pasal 40 sub c jo Pasal 33 ayat (1) dengan unsur tindak pidana: mengedarkan, mengekspor, mem pertunjukkan dan/atau menayangkan film yang tidak disensor oleh lembaga sensor film;

4) Pasal 41 ayat (1) sub a dengan unsur tindak pidana: melakukan usaha perfilman tanpa izin (usaha perfilman);

5) Pasal 41 ayat (1) sub b dengan unsur tindak pidana: mengedarkan, mengekspor, mempertunjukkan atau menayangkan reklame film yang tidak disensor sehingga tidak mewujudkan arah dan tujuan penyelenggaraan perfilman;

6) Pasal 41 ayat (1) sub c dengan unsur tindak pidana: melakukan kerjasama dengan perusahaan perfilman asing tanpa izin;

7) Pasal 41 ayat (2) dengan unsur tindak pidana: perusahaan perfilman yang mengedarkan, mengekspor, mempertunjukkan, dan/atau menayangkan film dan/atau reklame film yang tidak memiliki izin usaha perfilman dan tidak memiliki tanda lulus sensor;

8) Pasal 44 ayat (1) dengan unsur tindak pidana: perusahaan/badan usaha yang tidak menggunakan kemampuan nasional yang telah tersedia dalam melakukan kegiatannya; pembuatan film oleh pihak asing yang 
menggunakan lokasi di Indonesia tanpa izin;

Di samping itu ada juga pasal yang berkenaan dengan kegiatan pengedaran film yaitu Pasal 26 ayat (1), yang menyebutkan bahwa, kegiatan pengedaran film dilakukan dengan memperhatikan nilai-nilai keagamaan dan sosial budaya yang hidup di kalangan masyarakat di daerah yang bersangkutan, ternyata tidak ada keterangannya lebih lanjut. Terlebih jika terjadi pelanggaran terhadap Pasal 26 tersebut tidak ada konsekuensinya sama sekali dalam Undang-undang Perfilman tersebut. Padahal cyber child pornography terkait dengan pelanggaran terhadap nilai-nilai keagamaan, namun demikian tidak dapat di jangkau juga oleh Pasal ini.

\section{b. Sistem Perumusan Pertang- gungjawaban Pidana Dalam Undang-Undang Perfilman}

Melihat perumusan ketentuan pidana dalam Undang-undang Perfilman sebagaimana diatur dalam Pasal 40 sampai dengan Pasal 44 maka dapat diidentifikasikan bahwa pelaku tindak pidana atau yang dapat dimintakan pertanggung jawaban pidana dalam Undang-undang Perfilman adalah meliputi individu/orang per orang dan korporasi. Ini terbukti dari ketentuan pasal-pasal tersebut yang diawali dengan kata "Barang siapa ..." dan ...perusahaan/badan usaha...".
Masalah pertanggungjawaban pidana berkaitan erat dengan pelaku tindak pidana. Untuk pasal yang diawali dengan kata "Barang siapa...", maka yang dimaksud pelaku dalam pengertian kalimat ini adalah individu dan badan hukum. Hal ini bisa dilihat dalam ketentuan Pasal 40 dan 41 Undangundang No 8 tahun 1992, serta ketentuan tentang badan hukum yang disebut dalam Pasal 9 ayat (1) dan ayat (2), Pasal 41 ayat (2), Pasal 44 UU No 8 tahun 2002 sebagai Perusahaan perfilman.

\section{c. Sistem Perumusan Sanksi, Jenis Sanksi dan Lamanya Sanksi Pidana Dalam Undang-Undang Perfilman}

Sistem perumusan sanksi pidana dalam Undang-undang Perfilman adalah alternatif kumulatif. Hal ini bisa dilihat dalam perumusannya yang menggunakan kata “...dan/atau...", yaitu antara penjara dengan denda, atau kurungan dengan denda, serta antara pidana penjara/ kurungan dengan denda yang juga dikumulatifkan pula dengan sanksi administratif dalam Pasal 44. Namun demikian ketentuan tentang sanksi administratif tidak ada penjelasannya lebih lanjut terutama jenis atau bentuk sanksi administratif tersebut. Dalam Pasal 44 tersebut hanya mengamanatkan bahwa ketentuan lebih lanjut tentang sanksi administratif diatur dengan Peraturan Pemerintah. 
2. Undang-Undang Nomor 36 Tahun 1999 Tentang Telekomunikasi

\section{a. Sistem Perumusan Tindak Pidana Dalam Undang-undang Teleko- munikasi}

Ketentuan pidana dalam Undangundang Telekomunikasi tercantum dalam Pasal 47 sampai dengan 57.

Berdasar pasal-pasal tersebut diatas, unsur-unsur pasal pada tiap-tiap tindak pidana yaitu:

1) Pasal 47 jo Pasal 11 ayat (1) dengan unsur pidananya: penyelenggaraan jaringan telekomunikasi yang tanpa izin;

2) Pasal 48 jo Pasal 19 dengan unsur pidananya: penyelenggaraan jaringan telekominikasi menjamin kebebasan pengunanya dalam memilih jaringan lain untuk pemenuhan kebutuhan komunikasi;

3) Pasal 49 jo Pasal 20 dengan unsur pidananya: penyelenggara komunikasi tidak memberikan prioritas untuk pengiriman, penyaluran, dan penyampaian informasi penting yang menyangkut kepentingan $\mathrm{Ne}$ gara, keselamatan jiwa manusia dan harta benda, bencana alam, marabahaya, dan/ atau wabah penyakit;

4) Pasal 50 jo Pasal 22 dengan unsur pidannya: melakukan perbuatan tanpa hak, tidak sah, atau memanipulasi akses ke jaringan telekominikasi; dan/ atau akses ke jaringan telekomunikasi khusus;

5) Pasal 51 jo Pasal 29 ayat (1) atau ayat (2) dengan unsur pidananya: penyambungan te-lekomunikasi khusus ke jaringan lain;

6) Pasal 52 jo Pasal 32 ayat (1) dengan unsur pidananya: memperdagangkan, merakit, membuat dan memasukkan ke wilayah Indonesia tanpak memenuhi syarat teknis dan izin,

7) Pasal 53 jo Pasal 33 ayat (1) atau ayat (2) dengan unsur pidananya: penggunaan spectrum frekuensi dan orbit satelit tanpak izin pemerintah dan tidak sesuai dengan peruntukannya dan saling meng-ganggu;

8) Pasal 54 jo Pasal 35 ayat (2) atau Pasal 36 ayat (2) dengan unsur pidananya: kapal berbendera asing dan pesawat udara asing menggunakan frekuensi radio di luar peruntukannya;

9) Pasal 55 jo Pasal 38 dengan unsur pidananya: menimbulkan gangguan fisik dan elektro-magnetik terhadap penyelenggaraan telekomunikasi;

10) Pasal 56 jo Pasal 40 dengan unsur pidananya: penyadapan informasi yang disalurkan melalui jaringan telekomunikasi;

11) Pasal 57 jo Pasal 42 ayat (1) dengan unsur pidananya: tidak menjaga kerahasiaan informasi yang dikirim. Berdasarkan ketentuan pidana tersebut di atas, unsur tindak pidana yang dapat diidentifikasi adalah : 
1) Sifat melawan hukum, meskipun tidak disebutkan secara tegas, tetapi dapat dilihat pada rumusan "....Melanggar ketentuan sebagaimana dimaksud dalam pasal...". tidak dicantumkannya secara tegas unsur sifat melawan hukum dalam rumusan delik, menunjukkan bahwa dalam Undang-undang Telekomunikasi ada persamaan ide dasar dengan konsep KUHP 2008, yang menyebutkan bahwa meskipun unsur sifat melawan hukum tidak dicantumkan secara tegas delik itu harus selalu dianggap bertentangan dengan hukum.

2) Meskipun kata-kata "dengan sengaja" tidak dicantumkan secara tegas, apabila dilihat dari unsurunsur tindak pidana yang ada, maka tindak pidana yang dilakukan didasarkan pada unsur kesengajaan atau dolus.

Memperhatikan berbagai tindakan yang dikriminalisasikan dalam Undangundang Nomor 36 tahun 1999 di atas, belum Nampak ada kriminalisasi terhadap penyalahgunaan izin telekomunikasi yang dimiliki untuk melakukan penyebarluasan hal yang bersifat pornografi anak dengan mengunakan saranan telekomunikasi.

Bila diperhatikan dalam Undangundang No 36 tahun 1999 tersebut, kualifikasi delik diatur dalam Pasal 57 yang menyatakan bahwa Perbuatan sebagaimana dimaksud dalam Pasal 47 sampai dengan 57 Undang-undang Telekomunikasi adalah kejahatan. Akan tetapi, bila diteliti lebih lanjut, ada pasal yang sebenarnya apabila ada pelanggaran dapat dikenai pidana tetapi hal itu tidak ada pengaturan lebih lanjut. Pada bagian kelima tentang Hak dan Kewajiban Penyelenggara dan Masyarakat Pasal 21 Undang-undang Telekomunikasi menyebutkan:

Penyelenggara telekomunikasi dilarang melakukan kegiatan usaha penyelenggaraan telekomunikasi yang bertentangan dengan kepentingan umum, kesusilaan, keamanan, atau ketertiban umum.

Terhadap ketentuan dari Pasal 21 ini, apabila terjadi pelanggaran tidak ada sanksi pidananya. Padahal baik kepentingan umum, kesusilaan, keamanan dan ketertiban umum, kesemuanya memiliki kepentingan hukum yang juga harus mendapat perlindungan dengan melalui hukum pidana.

Dalam Pasal 49 dinyatakan bahwa pelanggaran terhadap ketentuan Pasal 20 akan dikenai ancaman pidana penjara paling lama 2 (dua) tahun dan/ atau pidana denda paling banyak Rp.200.000.000,00 (Dua Ratus Juta Rupiah). Pasal 20 berisi:

Setiap penyelenggara telekomunikasi wajib memberikan prioritas untuk pengiriman, penyaluran, dan penyam- 
paian informasi penting yang menyangkut:

a) keamanan negara;

b) keselamatan jiwa manu-sia dan harta benda;

c) bencana alam;

d) marabahaya; dan atau

e) wabah penyakit.

Apabila terjadi pelanggaran Pasal 20 ini seyogyanya diancam pidana penjara diatas 2 (dua) tahun, mengingat rumusan Pasal 20 yang didalamnya terkandung kepentingan hukum yang lebih penting dari sekedar penyelenggaraan telekomunikasi tampak ada izin dari Menteri, yang diancam pidana 6 (enam) tahun penjara. Nilai lebih yang terkandung di dalam rumusan Pasal 20 ini seharusnya diberi perlindungan dengan hukum pidana karena menyangkut kepentingan masyarakat secara luas.

\section{b. Sistem Perumusan Pertang- gungjawaban Pidana Dalam Undang-undang Telekomuni-kasi}

Masalah pertanggungjawaban pidana erat kaitannya dengan pelaku tindak pidana.

Pada pasal-pasal mengenai ketentuan pidana, yaitu Pasal 47 sampai dengan Pasal 57, diawali dengan:

1) "barangsiapa....",

2) "penyelenggara jasa telekomunikasi....".
Ada pengecualian yaitu pada Pasal 48, yang dimulai dengan "penyelenggaraan jaringan tele-komunikasi....".

Untuk pasal-pasal yang diawali dengan "barangsiapa...", maka yang termasuk dalam pengertian kalimat ini adalah:

1) Individu;

2) Badan hukum; hal ini sesuai dalam Pasal 1 angka 8 tentang tentang ketentuan umum menyebutkan bahwa penyelenggaraan telekomunikasi adalah Perorangan, Korporasi, Badan Usaha Milik Daerah (BUMD), Badan Usaha Milik Negara (BUMN), Badan Usaha Swasta, Instansi Pemerintah dan Instansi Pertahanan Keamanan Negara. Selain itu juga memperhatikan ketentuan lebih lanjut tentang kriteria badan hukum yang dapat disebut sebagai penyelenggara jaringan telekomunikasi dan atau penyelenggara jasa telekomunikasi menurut Pasal 7 ayat (1) huruf a dan huruf $b$ Undang-undang telekomunikasi.

3) Badan hukum, merujuk pada ketentuan Pasal 7 ayat (1) huruf c, yaitu penyelenggaraan telekomunikasi khusus dapat dilakukan oleh:

a) Perorangan;

b) Instansi pemerintah

c) Badanhukum selain penyelenggara jaringan telekomunikasi dan/atau penyelenggara jasa telekomunikasi; 
Mengenai pertanggungjawaban pidana dalam Undang-undang Nomor 36 tahun 1999 ini, dapat dilihat sebagai berikut:

1) Pertanggungjawaban pidana antara individu dan badan hukum tidak dibedakan;

2) Serta tidak ada penjelasan secara terperinci mengenai pertanggungjawaban pidana oleh korporasi;

3) Aturan pemidanaan yang sama baik untuk individu dan badan hukum;

4) Apabila aturan pemidanaan juga diterapkan pada badan hukum, maka pidana denda yang diancamkan terhadap korporasi bersifat tunggal, artinya terhadap korporasi tidak ada alternatif dikenakan pidana lain, terlebih lagi tidak mungkin dikenakan tindakan karena juga tidak ada ketentuannya;

5) Korporasi tidak mungkin di-kenakan pidana penjara;

6) Pidana penjara yang diancamkan dapat dikenakan terhadap individu yang memang dianggap paling bertanggungjawab terhadap terjadinya tindak pidana tersebut. Penentuan orang yang paling bertanggungjawab ini harus berdasar pada ketentuan perundang-undangan yang tegas dan jelas;

7) Apabila Undang-undang menganggap korporasi dapat dipertanggungjawabkan seyogyanya juga dirumuskan secara terperinci dan tegas mengenai siapa saja yang dapat bertanggungjawab terjadinya tindak pidana, aturan pemidanaan harus jelas baik terhadap individu yang dianggap paling bertanggungjawab maupun korporasi dapat dalam bentuk jenis pidana selain pidana penjara, yaitu tindakan;

8) Pidana denda yang diancam dalam Undang-undang No 36 tahun 1999, apabila dikenakan terhadap korporasi dinilai terlalu rendah.

Korporasi melakukan tindak pidana, apabila telah dipenuhi hal-hal sebagai berikut:

1) Kapan suatu korporasi dikatakan telah melakukan tindak pidana. Hal ini harus disebutkan secara jelas dalam rumusan pasal, tentang hal-hal apa saja dipandang dapat dilakukan oleh korporasi sehingga disebut suatu tindak pidana;

2) Mengenai dapat dipertanggungjawabkannya korporasi, yang dimaksud adalah individu yang bertanggungjawab. Hal ini perlu lebih diperjelas, dalam arti, seseorang yang dianggap paling bertanggungjawab dalam pelaksanaan kewajibannya dalam penyelenggaraan korporasi, atau jajaran manajemen yang lebih berkuasa dan bertanggungjawab atas pelaksanaan keseharian dari korporasi tersebut, tentunya dengan melihat lebih cermat dalam Anggaran Dasar dan Anggaran Rumah Tangga 
korporasi bersangkutan. Undangundang harus memberikan pengaturan secara tegas dan jelas;

3) Mengenai dapat dipidananya korporasi. Terhadap korporasi, jenis pidana apa saja yang dapat dikenakan terhadapnya, tidak mungkin terhadap korporasi dikenakan pidana penjara. Apabila mungkin, disebutkan jenis tin-dakan apa yang akan dikenakan terhadapnya;

4) Undang-undang tidak menyebutkan secara tegas, kepada siapa pidana yang diancamkan akan dikenakan. Kepada korporasi, kepada pengurus atau kepada korporasi dan pengurus?.

Dalam kaitannya dengan Undangundang Telekomunikasi, tidak ada rumusan pasal yang menyebutkan kapan korporasi melakukan tindak pidana dan siapa yang bertanggungjawab, serta sistem pemidanaan bagi korporasi.

\section{c. Sistem Perumusan Sanksi, Jenis Sanksi dan Lamanya Sanksi Pidana Dalam Undang-Undang Telekomu- nikasi}

Sistem perumusan sanksi pidana adalah alternatif kumulatif, menginggat bentuk perumusannya adalah “...dan/ atau...". Kecuali dalam Pasal 53 ayat (2,) sanksi pidana berupa pidana penjara diancamkan secara tunggal, karena mengakibatkan matinya seseorang.

\section{1) Sistem Perumusan Jenis Sank-si Pidana Dalam Undang-Undang Telekomunikasi}

Di dalam Undang-undang Telekomunikasi ini dikenal dua jenis sanksi pidana (Strafsoot) yaitu:

a) Pidana penjara;

b) Pidana denda.

Pidana penjara dikenakan untuk semua jenis kejahatan yang disebut dalam Undang-undang Telekomunikasi, dengan tidak memberi perbedaan apabila pelaku tindak pidana adalah manusia atau badan hukum.

Selama masih digunakannya KUHP, pengenaan sanksi pidana tersebut adalah sesuai dengan apa yang diatur oleh KUHP. Meskipun demikian, seyogyanya dibedakan antara manusia dan badan hukum, karena pada kejahatan yang dilakukan oleh badan hukum pertanggungjawaban pidana ada pada Pengurus atau Dewan Komisaris, terhadap badan hukum tidak dapat melaksanakan pidana penjara.

Selain pidana penjara dan pidana denda, ada pula tindakan yang diatur dalam Pasal 58 yang menyebutkan bahwa alat dan perangkat telekomunikasi yang digunakan dalam tindak pidana sebagaimana dimaksud dalam Pasal 47, Pasal 48, Pasal 52 dan Pasal 56 dirampas untuk Negara dan/ atau dimusnahkan sesuai Peraturan perundang-undangan yang berlaku.

2) Sistem Perumusan Lamanya Pidana Dalam Undang-Undang Telekomunikasi 
Perumusan lamanya pidana dalam Undang-undang Telekomunikasi adalah:

a) Maksimum khusus pidana penjara berkisar antara 1 tahun - 15 tahun;

b) Maksimum khusus pidana denda berkisar antara 100.000.000.00600.000.000.00.

Kurang tepat digunakan pidana penjara kepada korporasi antara lain karena maksimum khusus yang diterapkan berkisar antara 1 (satu) tahun penjara (Pasal 48) sampai 15 (lima belas) tahun penjara (Pasal 53 ayat (2)), selain itu juga kurang jelas siapa yang harus bertanggungjawab.

Pidana denda yang dikenakan kepada korporasi apabila dinilai secara nominal, dengan maksimum khusus denda berkisar antara Rp. 100.000.000,00 (Seratus Juta Rupiah) sampai Rp. 600.000.000,00 (Enam Ratus Juta Rupiah), jumlahnya sangat sedikit dibandingkan dengan keuntungan yang diperoleh dari hasil kejahatannya.

\section{3) Pedoman Pemidanaan Dalam Undang-Undang Telekomunikasi}

Pada Undang-undang Tele-
komunikasi tidak ada pengaturan secara tegas dan jelas yang bersifat sebagai pedoman pemidanaan atau cara bagaimana pidana dilaksanakan (strafmodus), dalam hal:

a) Pidana denda tidak dibayar oleh korporasi; b) Tidak ada pedoman pe-midanaan bagi hakim dalam penjatuhan pidana, terutama jika muncul percobaan dan penyertaan dalam melanggar ketentuan diatas.

\section{Dalam Undang-Undang No-mor 40 Tahun 1999 Tentang Pers}

Undang-undang ini diundangkan pada tanggal 23 September 1999. Ketentuan pidana dalam Undang-undang Nomor 40 tahun 1999 tentang Pers terdapat dalam Bab VIII Pasal 18,

Dalam Undang-undang ini tidak diatur tentang kualifikasi delik, tentunya yang demikian itu akan berpengaruh terhadap sistem penegakan hukum dibidang Pers itu sendiri. Seharusnya dalam Undang-undang tersebut harus mencantukkan kualifikasi delik karena itu sangat penting selama masih berlaku KUHP yaitu sebagai pedoman umum bagi semua Undang-undang diluar KUHP.

Berdasarkan ketentuan Pasal 18 Undang-undang Pers tersebut di atas, maka dapat diidentifikasikan perbuatan yang dilarang (unsur tindak pidana) pada Pasal 18 tersebut pada tiap-tiap ayatnya sebagai berikut:

1) Pasal 18 ayat (1) jo Pasal 4 ayat (2) dengan unsur: melakukan tindakan yang berakibat menghambat atau menghalangi pelaksanaan penyensoran, pembredelan, atau pelarangan penyiaran; 
2) Pasal 18 ayat (1) jo Pasal 4 ayat (3) dengan unsur: melakukan tindakan yang berakibat menghambat atau menghalangi pelaksanaan Hak Pers Nasional untuk mencari, memperoleh, dan menyebarluaskan gagasan dan informasi;

3) Pasal 18 ayat (2) jo Pasal 5 ayat (1) dengan unsur: Pers Nasional memberikan peristiwa dan opini dengan tidak menghormati normanorma agama dan rasa kesusilaan masyarakat serta asas praduga tak bersalah.

4) Pasal 18 ayat (2) jo Pasal 5 ayat (2) dengan unsur: Perusahaan Pers tidak melayani hak jawab;

5) Pasal 18 ayat (2) jo Pasal 13 dengan unsur: Perusahaan iklan yang memuat iklan yang berakibat merendahkan martabat suatu agama dan atau mengganggu kerukunan hidup antar umat beragama, serta bertentangan dengan rasa kesusilaan masyarakat; memuat iklan munuman keras, narkotika, psikotropika, dan zat aditif lainnya yang bertentangan dengan ketentuan peraturan perundangan yang berlaku; serta memuat iklan dengan meragakan wujud rokok dan atau penggunaan rokok;

6) Pasal 18 ayat (3) jo Pasal 9 ayat (2) dengan unsur: Perusahaan Pers tidak berbentuk badan hukum Indonesia;

7) Pasal 18 ayat (1) jo Pasal 12 dengan unsur: Perusahaan Pers tidak mengumumkan Nama, Alamat dan Penanggungjawab secara terbuka melalui media yang bersangkutan, serta Penerbitan Pers tidak menyebutkan Nama dan Alamat Penerbitan.

Mengenai unsur sifat 'melawan hukum', dalam undang-undang Pers tersebut disebutkan secara tegas dalam Pasal 18 ayat (1), walaupun ada juga yang tidak disebutkan secara tegas seperti dalam Pasal 18 ayat (2) dan ayat (3), namun demikian unsur 'sifat melawan hukum' tersebut dapat dilihat pada perumusan “....melanggar ketentuan pasal..." seperti dirumuskan dalam Pasal 18 ayat (2) dan ayat (3). Meskipun unsur 'sifat melawan hukum' tidak dicantumkan secara tegas khususnya dalam Pasal 18 ayat (2) dan (3), tetapi suatu delik harus tetap dianggap bertentangan dengan hukum.

\section{b. Sistem perumusan pertang- gungjawaban pidana dalam Undang-Undang Pers}

Melihat perumusan ketentuan pidana dalam Undang-undang Pers sebagaimana diatur dalam Pasal 18, maka dapat diidentifikasikan bahwa pelaku tindak pidana atau yang dapat dimintakan pertanggungjawaban pidana dalam Undang-Undang Pers adalah meliputi individu/orang per orang dan koorporasi. Ini terbukti dari ketentuan pasal-pasal tersebut yang diawali dengan kata "Setiap orang ..." dan " Perusahaan 
Pers..." dalam Pasal 18 Undang-undang Pers.

Masalah pertanggungjawaban pidana berkaitan erat dengan pelaku tindak pidana. Untuk pasal yang diawali dengan kata "Setiap orang...", maka yang dimaksud pelaku dalam pengertian kalimat ini adalah individu dan badan hukum. Hal ini bisa dilihat dalam ketentuan Pasal 18 ayat (1) dan diatur lebih lanjut dalam Pasal 1 angka 2 Undang-undang Nomor 40 tahun 1999 mengenai ketentuan tentang Perusahaan Pers. Sedangkan untuk badan hukum/ koorporasi dapat dilihat dalam Pasal 9 ayat (2) di mana setiap Perusahaan Pers harus berbentuk badan hukum Indonesia seperti disebutkan dalam Pasal 9 ayat (2) Undang-undang No. 40 tahun 1999.

Namun demikian dalam Undangundang tersebut tidak ada ketentuan mengenai pedoman pemidanaan terutama terhadap denda yang tidak terbayar, sehingga secara otomatis akan kembali kepada sistem induknya yaitu KUHP, yang ternyata tidak dapat diterapkan terhadap korporasi. Padahal dalam Undang-undang tersebut dengan jelas disebutkan bahwa korporasi sebagai salah satu subyek yang dapat dimintakan pertanggungjawabannya dalam hukum pidana, sehingga dapat disimpulkan bahwa dalam Undang-undang Pers juga belum terdapat ketentuan tentang pedoman pemidanaan atau cara bagaimana pidana dilaksanakan (strafmodus) sebagai pedoman bagi hakim.

\section{c. Sistem Perumusan Sanksi, Jenis Sanksi dan Lamanya Pidana Dalam Undang-Undang Pers}

Sistem perumusan sanksi pidana dalam Undang-Undang Pers adalah alternatif dan sistem perumusan secara tunggal. Untuk sistem perumusan alternatif bisa dilihat dalam perumusan Pasal 18 ayat (1) yang menggunakan kata "...atau...", dan sistem tunggal dalam Pasal 18 ayat (2) dan ayat (3), yang mengancamkan sanksi pidana berupa pidana denda secara tunggal sebagai pidana pokok yang dirumuskan secara tunggal.

\section{1) Sistem Perumusan Jenis Sanksi Pidana Dalam Undang-Undang Pers}

Jenis-jenis saksi (strafsoort) pidana dalam Undang-undang Pers ini ada dua jenis yaitu pidana penjara dan denda, sedangkan sanksi administratif/ tindakan tidak diatur, padahal pelaku tindak pidana dalam Undang-undang Pers selain individu adalah Korporasi/ badan hukum yang hanya bisa dijatuhi denda saja, sehingga jika denda tidak terbayar tidak ada alternatif lain selain denda, sehingga seyogyanya sanksi administratif diatur dalam undang-undang ini. 
2) Sistem Perumusan Lamanya Pidana Dalam Undang-Undang Pers

Sistem Perumusan lamanya pidana (strafmaat) dalam Undang-undang Pers ini adalah:

a) Maksimum khusus pidana penjara maksimal 2 (dua) tahun.

b) Maksimum khusus pidana denda berkisar antara $\mathrm{Rp}$ 100.000.000,(Seratus Juta Rupiah) sampai dengan Rp 500.000.000,- (Lima ratus juta rupiah).

3) Pedoman Pemidanaan Dalam Undang-Undang Pers

Dalam undang-undang Pers tidak ada pedoman pemidanaan (strafmodus) mengenai :

a) Pertanggungjawaban korporasi;

b) Dalam hal yang bagaimana korporasi dikatakan melakukan tindak pidana dan siapa yang bertanggungjawab ketika korporasi melakukan tindak pidana;

4 Undang-Undang Nomor 23 Tahun 2003 Tentang Per-lindungan Anak

a. Sistem Perumusan Tindak Pidana Dalam Undang-Undang Perlindungan Anak

Dalam Undang-undang Perlindungan Anak, ketentuan pidana dicantumkan pada Bab XII Pasal 77 sampai dengan Pasal 90. Pasal 90 Undang-undang tersebut memuat ketentuan pidana tentang korporasi.
Dalam kaitanya dengan Cyber Child Pornoghraphy (pornografi anak di internet), dapat dipergunakan rumusan Pasal 82 dan Pasal 88. Unsur-unsur tindak pidana dalam Pasal 82 adalah :

1) Melakukan kekerasan atau ancaman kekerasan;

2) Memaksa;

3) Melakukan tipu muslihat;

4) Serangkaian kebohongan;

5) Membujuk anak untuk me-lakukan atau membiarkan dilakukan perbuatan cabul.

Berdasarkan rumusan Pasal 82, dapat diidentifikasikan hal-hal sebagai berikut :

1) Secara tegas dan jelas menyebutkan "...dengan sengaja....", ini menunjukkan tindak pidana yang didasarkan pasa asas kesalahan atau dolus;

2) Mengenai sifat melawan hukum tidak disebutkan secara tegas, tetapi tertuang dalam unsur-unsur : melakukan kekerasan atau ancaman kekerasan, memaksa, melakukan tipu muslihat, serangkaian kebohongan, atau membujuk anak untuk melakukan atau membiarkan dilakukan perbuatan cabul. Rumusan tindak pidana Pasal 82 memang tidak disebutkan secara jelas dan tegas tentang unsur sifat melawan hukum. Hal ini sesuai dengan Pasal 11 ayat (3) Konsep KUHP 2008 yang menegaskan bahwa setiap 
tindak pidana selalu dipandang bersifat melawan hukum, kecuali ada alasan pembenar. Jika Undangundang Perlindungan Anak memiliki kesamaan ide dasar dengan konsep KUHP tahun 2008 maka tidak perlu disebutkan secara tegas unsur sifat melawan hukum dalam setiap rumusan delik. Selain itu Pasal 11 ayat (2) Konsep KUHP 2008 menyatakan untuk dinyatakan sebagai tindak pidana, selain perbuatan tersebut dilarang dan diancam pidana oleh peraturan perundang-undangan, harus juga bersifat melawan hukum dan bertentangan dengan hukum yang hidup dalam masyarakat. Jelas sekali bahwa unsur-unsur tidak pidana Pasal 82, selain bersifat melawan hukum juga bersifat bertentangan dengan hukum yang hidup dalam masyarakat.

Pasal 82 dapat digunakan untuk menjerat pelaku tindak pidana cyber child pornography (pornografi anak di internet), alasannya: apabila rumusan pasal atau terpenuhinya unsur-unsur tindak pidana dalam Pasal 82, yaitu dengan melakukan salah satu kegiatan diatas yang kesemuanya bertujuan supaya anak melakukan atau membiarkan dilakukan perbuatan cabul. Disini tidak dipermasalahkan mengenai penyebarluasan hasil perbuatan tersebut, artinya apakah hasil itu disiarkan, didistribusikan melalui media komunikasi, dimasukkan 14 dalam majalah dimana semua orang dapat membaca dan melihat.

Unsur-unsur tindak pidana dalam Pasal 88 adalah sebagai berikut :

1) Mengeksploitasi ekonomi dan seksual anak

2) Dengan maksud untuk menguntungkan diri sendiri atau orang lain.

Berdasarkan rumusan Pasal 88, diidentifikasi hal-hal sebagai berikut :

1) Tidak ada penegasan tentang kesengajaan. Digunakan “....dengan maksud....", hal ini merupakan unsur kesengajaan dalam rumusan delik. Corak kesengajaan yang ada adalah kesengajaan dengan sadar kemungkinan atau dolus even-tualis. Ada rumusan "...untuk menguntungkan diri sendiri atau orang lain...", ini menunjukkan ada kesengajaan. Melakukan suatu hal untuk keuntungan diri sendiri atau orang lain, bukan suatu kealpaan, tetapi suatu kesengajaan. Dengan orientasi Pasal 39 ayat (2) Konsep KUHP 2008 yang menyebutkan bahwa perbuatan yang dapat dipidana adalah perbuatan yang dilakukan dengan sengaja, kecuali peraturan perundangundangan menentukan dengan tegas bahwa suatu tindak pidana dilakukan dengan kealpaan dapat dipidana. Dapat dikatakan, bahwa rumusan tindak pidana dalam Pasal 88 ini mengandung unsur kesengajaan, lebih 
ditegaskan dengan adanya “.... dengan maksud...", hal ini bukanlah suatu kealpaan. Selain itu melakukan eksploitasi ekonomi atau seksual anak, jelas dilakukan dengan sengaja dan akal sehat, bukan dilakukan karena kealpaan.

2) Unsur sifat melawan hukum tidak dicantumkan secara tegas, tetapi hal ini secara implisit dapat diketahui dari rumusan "..... mengeksploitasi ekonomi atau seksual anak....". melakukan eksploitasi ekonomi atau eksploitasi seksual terhadap anak, merupakan pelanggaran terhadap kepentingan hukum anak, yang seharusnya dilindungi dan bukannya justru dieksploitasi untuk kepentingan diri sendiri atau orang lain, baik eksploitasi ekonomi atau eksploitasi seksual, selain itu hal tersebut juga betentangan dengan hukum yang hidup dalam masyarakat. Meskipun unsur sifat melawan hukum tidak disebut secara tegas, namun dengan berorientasi pada Pasal 11 ayat (3) konsep KUHP 2008 bahwa setiap tindak pidana selalu dipandang bersifat melawan hukum, kecuali ada alasan pembenar.

\section{b. Sistem Perumusan Pertang- gungjawaban Dalam Undang- Undang Perlindungan Anak}

Pertanggungjawaban dalam Undang-undang Perlindungan Anak dimulai dengan "setiap orang". Undangundang Perlindungan Anak telah menyebutkan secara tegas pada Bab I Ketentuan Umum Pasal 1 angka 16 bahwa setiap orang adalah orang perorangan atau korporasi.

Penegasan dari undang-undang sendiri merupakan hal yang tepat, sehingga tidak menimbulkan keraguraguan dalam masyarakat, mengenai apakah korporasi termasuk sebagai subyek hukum pidana dalam Undangundang Per-lindungan Anak ini.

Melihat rumusan pasal dalam Undang-undang Perlindungan Anak, pertanggungjawaban pidana berda-sarkan kesalahan (liability based on fault), hal ini dapat dilihat secara jelas pada pasalpasal yang memuat ketentuan pidana, kesalahan dalam hal ini adalah dalam bentuk kesengajaan (dolus).

Untuk adanya kesalahan dalam arti ada pertanggungjawaban pidana, terhadap tindakan pelaku harus bersifat melawan hukum. Apabila pelaku adalah korporasi, masalah pertanggungjawaban pidana harus dikaji lebih mendalam, artinya bahwa pengurus juga harus diperiksa tentang ada atau tidak adanya unsur kesengajaan.

Untuk kesengajaan ini dalam Pasal 82 disebutkan secara tegas, namun pada Pasal 88 tidak disebutkan secara tegas. Kesalahan dalam arti yang seluas-luasnya adalah hubungan batin antara si pembuat terhadap perbuatan yang dilakukannya, yang dicelakakan kepada si pembuat itu. 
Hubungan batin ini bisa berupa sengaja atau alpa. ${ }^{2}$

Terhadap hal yang dilakukannya, bentuk atau corak kesengajaan dapat dibedakan dalam 3 (tiga) jenis, yaitu : Kesengajaan sebagai maksud, Kesengajaan dengan radar kepastian, Kesengajaan dengan radar kemungkinan. ${ }^{3}$

c. Sistem Perumusan Sanksi, Jenis Sanksi, Lamanya Pidana Serta Pedoman Pemidanaan Dalam Undang-Undang Perlindungan Anak 1) Sistem Perumusan Jenis Sanksi Pidana Dalam Undang-Undang Perlindungan Anak

Perumusan jenis sanksi pidana (strafsoort) dalam Undang-undang Perlindungan Anak terdiri dari pidana penjara dan pidana denda. Hampir dalam keseluruhan pasal dari semua ketentuan pidana dalam Undang-undang Perlindungan Anak mengunakan pidana penjara dan pidana denda.

Undang-undang Perlindungan Anak tidak merumuskan jenis pidana administratif atau tindakan kepada kepada korporasi. Untuk korporasi, pidana dapat dijatuhkan kepada pengurus dan/ atau korporasinya. Hal ini dapat dikatakan bahwa pidana penjara dapat dikenakan kepada pengurus korporasi, karena untuk korporasi hanya dikenakan

\footnotetext{
${ }^{2}$ Op. Cit hal 102

${ }^{3}$ Op. Cit hal 103 16
}

pidana denda dengan penambahan 1/3 pidana denda masing-masing.

2) Sistem Perumusan Lamanya Pidana Dalam Undang-Undang Perlindungan Anak

Perumusan lamanya pidana (strafmaat) dalam Undang-undang perlindungan anak, sebagai berikut :

a) Minimum umum untuk pi-dana penjara berkisar antara 2 sampai 5 tahun;

b) Maksimum khsusus untuk pidana penjara berkisar an-tara 3 sampai 20 tahun;

c) Minimum umum untuk pi-dana denda berkisar antara Rp. 20.000.000,00 sampai Rp. 60.000.000,00;

d) Maksimum khusus untuk pidana denda berkisar antara Rp. 72.000.000,00 sampai 500.000.000,00.

Dalam hal tindak pidana dilakukan oleh korporasi, maka ancaman pidana dalam tiap-tiap pasal dapat dikenakan kepada pengurus dan/ atau korporasinya.

Untuk pidana denda bagi korporasi ditambah $1 / 3$ dari ketentuan pidana yang pada tiap-tiap pasal.

\section{1) Pedoman Pemidanaan Dalam Undang-undang Perlindungan Anak \\ Dalam Undang-undang per- lindungan anak tidak ada pedoman pemidanaan (strafmodus) mengenai :}


a) Percobaan dan penyertaan;

b) Sistem perumusan jenis sanksi, lamanya pidana bagi percobaan dan penyertaan.

Untuk korporasi ada pengaturan secara tegas yaitu dalam Pasal 90 ayat (2), yaitu pidana yang dijatuhkan kepada korporasi hanya pidana denda dengan ketentuan pidana denda yang dijatuhkan ditambah $1 / 3$ (sepertiga) pidana denda masing-masing sebagaimana tercantum dalam rumusan masing-masing pasal.

Pidana tambahan yang dapat dikenakan kepada korporasi, adalah:

a) Pencabutan hak-hak tertentu;

b) Perampasan barang-barang tertentu dan tagihan;

c) Pembayaran keputusan hakim

Jika pengurus yang bertanggungjawab, selain pidana pokok yang berupa pidana penjara dan pidana denda, dapat pula dikenakan pidana tambahan berupa pembayaran ganti kerugian serta pengumuman keputusan hakim.

Dalam Undang-undang Perlindungan Anak, belum ada pengaturan jika korporasi tidak membayar pidana denda, apakah terhadap korporasi tadi dapat dikenakan pidana tambahan, hal inipun tidak mungkin karena tidak diatur dalam undang-undang. Demikian pula apabila dikenakan tindakan, juga tidak mungkin karena hal inipun tidak diatur dalam undang-undang.

\section{Undang-Undang Nomor 32 Tahun 2002 Tentang Penyiaran}

Menyiarkan atau menyebarluaskan informasi dilakukan melalui radio, televisi, multimedia, atau media informasi lainnya. Salah satu media informasi adalah internet sebagai media informasi dari sisi teknologi informasi. Sebagai media informasi yang bersifat terbuka, penyebarluasan informasi melalui internet dapat terlaksana dengan cepat, mudah diperoleh, salah satunya penyebarluasan cyber child pornography (pornografi anak melalui internet).

Sesuai dengan Pasal 13 Undangundang Nomor 32 tahun 2002 tentang Penyiaran, jasa penyiaran terdiri atas jasa penyiaran radio dan jasa penyiaran televisi, jasa penyiaran tersebut diselenggarakan oleh Lembaga Penyiaran Publik, Lembaga Penyiaran Swasta, Lembaga Penyiaran Komunitas dan Lembaga Penyiaran Berlangganan.

\section{a. Sistem Perumusan Tindak Pidana Dalam Undang-Undang Penyiaran}

Ketentuan pidana dalam Undangundang Nomor 32 tahun 2002 ini terdapat pada Bab X mulai Pasal 59 sampai dengan Pasal 59, dan kualifikasi delik hanya mengenai 1 (satu) jenis tindak pidana yaitu kejahatan.

Undang-undang Nomor 32 tahun 2002 memasukkan pelanggaran yang bersifat pelanggaran administratif. 
Berdasarkan rumusan pasal ketentuan tindak pidana dalam Undangundang Penyiaran, dapat diidentifikasikan hal-hal sebagai berikut :

1) Meskipun kata-kata "dengan sengaja" tidak dicantumkan secara tegas, apabila dilihat dari unsur-unsur tindak pidana yang ada, maka tindak pidana yang dilakukan didasarkan pada unsur kesengajaan atau dolus. Pasal 39 ayat (2) Konsep KUHP 2008 menyebutkan bahwa perbuatan yang dapat dipidana adalah perbuatan yang dilakukan dengan sengaja, kecuali Peraturan perundang-undangan menentukan secara tegas bahwa suatu tindak pidana yang dilakukan dengan kealpaan dapat dipidana. Rumusan tindak pidana dalam Undang-undang Penyiaran berawal dari ide dasar yang sama dengan konsep.

2) Unsur melawan hukum dari setiap tindak pidana dapat dilihat pada unsur "melanggar ketentuan pasal...", yang tercantum pada setiap rumusan pasal. Secara umum dalam Undang-undang Penyiaran memang tidak sisebutkan secara jelas dan tegas pada setiap rumusan delik tentang unsur sifat melawan hukum. Hal ini sesuai dengan Pasal 11 ayat (3) konsep KUHP 2008 yang menegaskan bahwa setiap tindak pidana selalu dipandang bersifat melawan hukum, kecuali ada alasan pembenar. Jadi, tidak perlu disebutkan secara tegas unsur sifat melawan hukum dalam setiap rumusan delik.

\section{b. Sistem Perumusan Pertang- gungjawaban Pidana Dalam Undang-Undang Penyiaran \\ Menurut Undang-undang Nomor 32} tahun 2002 tentang Penyiaran, subyek hukum pidana adalah individu dan badan hukum atau korporasi. Dalam Undangundang Penyiaran tercantum pada Bab I Ketentuan Umum Pasal 1 angka 9 menyebutkan Lembaga Penyiaran adalah penyelenggara penyiaran, baik Lembaga Penyiaran Publik, Lembaga Penyiaran Swasta, Lembaga Penyiaran Komunitas maupun Lembaga Penyiaran Berlangganan yang dalam melaksanakan tugas, fungsi, dan tanggung jawabnya berpedoman pada Peraturan Perundangundangan yang berlaku. Lembaga penyiaran didirikan dalam suatu bentuk badan hukum, dengan demikian korporasi merupakan subyek hukum pidana dalam Undang-undang Penyiaran.

Internet service provider (ISP) sebagai korporasi penyelenggara jasa sambungan internet, perlu dilihat masuk katagori lembaga mana yang paling tepat. Dengan memperhatikan berbagai katagori lembaga penyiaran dalam Undang-undang Penyiaran, Internet Service Provider (ISP) dapat dimasukkan katagori sebagai Lembaga Penyiaran Berlangganan melalui satelit.

Rasio yang digunakan adalah bahwa untuk dapat terhubung dengan 
server di tempat lain digunakan fasilitas telekomunikasi yaitu telepon yang menggunakan satelit. Untuk dapat melakukan hubungan melalui internet dengan jasa internet service provide (ISP) dapat dengan cara berlangganan pada salah satu internet service provider (ISP) tertentu.

Dalam Pasal 25 ayat menyebutkan bahwa Lembaga Penyiaran Berlangganan sebagai-mana dimaksud dalam ayat (1) memancarluaskan atau menyalurkan materi siarannya secara khusus kepada pelanggan melalui radio, televisi, multimedia, atau media informasi lainnya. Undang-undang penyiaran tidak menyebutkan secara jelas dan tegas apa saja yang termasuk dalam katagori media informasi lainnya, dengan demikian maka internet dapat dikatagorikan sebagai media informasi lainnya.

Masalah pertanggungjawaban pidana berkaitan erat dengan subyek hukum pidana dalam Undang-undang Penyiaran, yaitu individu dan korporasi. Dalam Undang-undang Penyiaran menganut prinsip Liability Based On Fault atau pertanggungjawaban berdasarkan kesalahan, kesalahan yang dimaksud adalah kesalahan dalam bentuk kesengajaan (dulos).

Dalam permasalahan ini, yang dimaksudkan sebagai korporasi adalah internet service provider (ISP) sebagai penyedia jasa internet untuk melakukan komunikasi dengan server lain di tempat yang lain pula. Pada pembahasan tentang subyek hukum pidana, ISP dikatagorikan sebagai Lembaga Penyiaran Langganan.

Menurut undang-undang Penyiaran ada 4 (empat) jenis lembaga penyiaran, hal ini berarti bahwa seyogyanya ada pengaturan tersendiri secara lengkap dan jelas mengenai pertanggungjawaban pidana oleh korporasi yaitu lembaga penyiaran, yaitu dalam hal : kapan suatu korporasi dikatakan melakukan tindak pidana, siapa yang bertanggungjawab, sanksi pidana apa yang akan dikenakan terhadap korporasi tersebut? Ketiga masalah pokok mengenai pertanggung jawaban korporasi tidak diatur secara tegas dalam Undangundang Penyiaran.

Mengenai pertanggungjawaban pidana, dapat dilihat dalam Pasal 54 Undang-undang Nomor 32 tahun 2002 tentang Penyiaran. Pasal 54 Undangundang Penyiaran menyatakan Pimpinan badan hukum lembaga penyiaran bertanggung jawab secara umum atas penyelenggaraan penyiaran dan wajib menunjuk penanggung jawab atas tiaptiap program yang dilaksanakan.

Berdasarkan rumusan per tanggungjawaban tersebut diatas, dapat dikatakan sebagai berikut :

1) Pemimpin umum bertanggung-jawab secara umum, ini berarti bahwa pemimpin umum juga bertang- 
gungjawab secara hukum;

2) Tidak dirumuskan secara tegas mengenai ada atau tidaknya pertanggungjawaban secara hukum yang dapat dilimpahkan secara tertulis kepada penanggungjawab masing-masing bidang;

3) Pertanggungjawaban pidana bersifat strict liability.

Apabila Undang-undang tidak memberi aturan yang jelas dalam hal pertanggungjawaban korporasi, siapa yang bertanggungjawab dapat dilihat pada ketentuan dalam Anggaran Dasar dari korporasi tersebut. Hal penting lainnya adalah bahwa ada unsur kesalahan yang berupa kesengajaan (dolus) oleh orang yang melakukan tindak pidana. Unsur kesalahan ini merupakan hal yang harus ada untuk mengetahui pertanggung jawaban pidananya.

Ketiadaan aturan yang jelas dan tegas mengenai pertanggung jawaban korporasi dapat menimbulkan masalah tersendiri pada saat penerapan ketentuan pidana undang-undang penyiaran.

\section{c. Sistem Perumusan Sanksi, Jenis Sanksi, Lamanya Pidana Serta Pedoman Pemidanaan Dalam Undang-Undang Penyiaran}

Dalam Undang-undang Penyiaran, sistem perumusan sanksi pidana adalah sebagai berikut :

1) Untuk Pasal 57 dan Pasal 58 pidana pokok dirumuskan secara alternatif komulatif;

2) Untuk Pasal 59 hanya diancam pidana denda sebagai pidana pokok yang dirumuskan secara tunggal.

Sanksi pidana diatas diancam kepada para pelaku kejahatan yang sebenarnya para pelaku kejahatan itu sendiri terdiri dari individu dan korporasi. Untuk individu, dapat dikenakan pidana penjara dan pidana denda. Namun, tidak demikian dengan korporasi, yang hanya dapat dikenakan pidana denda saja.

Undang-undang penyiaran tidak memberi ketegasan pemidanaan terhadap korporasi, padahal dalam beberapa pasal mengenai lembaga penyiaran jelas disebutkan, bahwa lembaga penyiaran berbentuk badan hukum (Pasal 14 ayat (1) dan Pasal 16 ayat (1)).

Ada penegasan mengenai lembaga penyiaran berbentuk badan hukum, seyogyanya Undang-undang memberikan ketegasan pengaturan tentang ancaman pidana serta sanksi pidana terhadap korporasi.

Seyogyanya untuk korporasi hanya dapat dikenakan pidana denda dan apabila mungkin diikuti pula dengan tindakan atau pidana administratif, yang bentuknya disesuaikan dengan kepentingan korporasi. 
1) Sistem Perumusan Jenis Sanksi Pidana Dalam Undang-Undang Penyiaran

Sistem perumusan jenis sanksi pidana (strafsoort) dalam Undang-undang Penyiaran adalah pidana penjara dan pidana denda.

Perumusan jenis sanksi berupa pidana penjara/ atau pidana denda terdapat dalam Pasal 57 dan 58, untuk Pasal 59 hanya mengenakan pidana denda sebagai pidana pokok.

Dalam Undang-undang Penyiaran tidak ada aturan yang secara tegas mengatur pengenaan pidana penjara terhadap korporasi, hal ini berkaitan erat dengan pertanggungjawaban korporasi. Selain itu dalam Undang-undang Penyiaran, tidak ada ketentuan yang mengatur secara tegas dalam hal korporasi dikenai pidana denda yang kemudian pidana denda tersebut tidak dibayar. Karena tidak ada ketentuan yang tegas, apabila korporasi tidak membayar denda sebagaimana Putusan Pengadilan yang telah mempunyai kekuatan hukum tetap, hal ini akan merugikan Negara. Selain itu akan menimbulkan preseden yang kurang baik terhadap penegakan hukum Indonesia, dan ada kemungkinan pula hal ini terjadi dan diikuti oleh korporasi lain.

2) Sistem Perumusan Lamanya Pidana Dalam Undang-Undang Penyiaran
Sistem perumusan lamanya pidana (strafmaat) dalam Undang-undang Penyiaran adalah sebagai berikut :

a) Maksimal khusus pidana penjara berkisar antara 2 (dua) tahun sampai 5 (lima) tahun;

b) Maksimal khusus denda berkisar antara Rp. 200.000.000,00 (Dua Ratus Juta Rupiah) sampai Rp. 10.000.000.000,00 (Satu Milyar Rupiah).

Pidana penjara dikenakan untuk semua jenis kejahatan yang disebut dalam Undang-undang Penyiaran, dengan tidak memberi perbedaan apabila pelaku tindak pidana adalah manusia atau badan hukum.

Selama masih digunakannya KUHP, pengenaan sanksi pidana tersebut adalah sesuai dengan apa yang diatur oleh KUHP. Meskipun demikian, seyogyanya dibedakan antara manusia dan badan hukum, Karena pada kejahatan yang dilakukan oleh badan hukum pertanggungjawaban pidana ada pada pengurus atau dewan komisaris, terhadap badan hukum tidak dapat melaksanakan pidana penjara.

\section{3) Pedoman Pemidanaan Dalam \\ Undang-Undang Penyiaran \\ Undang-undang Penyiaran tidak} mencantumkan pedoman pemidanaan (strafmodus), seyogyanya hal ini perlu menginggat sebagai berikut : 
a) Korporasi sebagai subyek hukum dikenakan pidana penjara. Namun tidak ada pedoman pemidanaan yang tegas mengenai siapa yang dikenai pidana penjara jika terbukti korporasi memenuhi unsur-unsur tindak pidana. Korporasi tidak dapat dipenjara, yang dapat dipenjara adalah pengurus saja. Hal ini berkaitan dengan batasan pertanggungjawaban pengurus;

b) Korporasi dapat dikenai pidana denda. Namun tidak ada pedoman pemidanaan, apabila korporasi tidak membayar denda.

\section{Dalam Undang-Undang Nomor 11 Tahun 2008 Tentang Informasi Dan Transaksi Elektronik}

Dalam Undang-undang Nomor 11 tahun 2008 tentang Informasi dan Transaksi Elektronik, dimaksud dengan Informasi Elektronik adalah satu atau sekum-pulan data elektronik, termasuk tetapi tidak terbatas pada tulisan, suara, gambar, peta, rancangan, foto, electronic data interchange (EDI), surat elektronik (electronic mail), telegram, teleks, telecopy atau sejenisnya, huruf, tanda, angka, Kode Akses, simbol, atau perforasi yang telah diolah yang memiliki arti atau dapat dipahami oleh orang yang mampu memahaminya.

Undang-undang ini di undangkan pada tanggal 21 April tahun 2008 dalam Lembaran Negara RI tahun 2008 Nomor 58. Salah satu pertimbangan dalam penyususunan Undang-undang Informasi dan Transaksi Elektronik adalah bahwa globalisasi informasi telah menempatkan Indonesia sebagai bagian dari masyarakat informasi dunia sehingga mengharuskan dibentuknya pengaturan mengenai pengelolaan Informasi dan Transaksi Elektronik di tingkat Nasional sehingga pembangunan Teknologi Informasi dapat dilakukan secara optimal, merata, dan menyebar ke seluruh lapisan masyarakat guna mencerdaskan kehidupan bangsa.

\section{a. Sistem Perumusan Tindak Pidana Dalam Undang-undang Informasi dan Transaksi Elektronik}

Ketentuan pidana dalam Undangundang Informasi dan Transaksi Elektronik tercantum dalam Pasal 45 sampai dengan 52 .

Berdasarkan ketentuan pidana tersebut diatas, unsur tindak pidana yang dapat diidentifikasi adalah Mengenai unsur sifat 'melawan hukum', dalam undang-undang ITE tersebut disebutkan secara tegas, unsur 'sifat melawan hukum tersebut dapat dilihat pada perumusan “....setiap orang dengan sengaja dan tanpa hak atau melawan hukum sebagaimana dalam pasal..." seperti dirumuskan dalam Pasal 30 sampai dengan Pasal 37 tersebut di atas, sehingga dapat disimpulkan bahwa dengan disebutkannya secara tegas unsur 'sifat melawan hukum' terlihat ada kesamaan ide dasar antara Undangundang ITE dengan KUHP yang masih 
menyebutkan unsur sifat melawan hukumnya suatu perbuatan. Berbeda dengan Konsep KUHP yang menentukan bahwa meskipun unsur 'sifat melawan hukum' tidak dicantumkan secara tegas, tetapi suatu delik harus tetap dianggap bertentangan dengan hukum.

Istilah tindak pidana dalam Pasal 27 sampai dengan 37 yang disebutkan oleh Pasal 52 ayat (1) sampai (4) kurang tepat karena Pasal 27 sampai dengan Pasal 37 tidak merupakan tindak pidana dan tidak pernah disebutkan dalam ketentuan pidana undang-undang tersebut sehingga tidak dapat dikenakan pemberatan $1 / 3$ atau $2 / 3$ dari pidana pokok.

\section{b. Sistem Perumusan Pertang gung- jawaban Pidana Dalam Undang- Undang Informasi dan Transaksi Elektronik}

Pelaku tindak pidana atau yang dapat dimintakan pertanggung jawaban pidana dalam Undang-undang Informasi dan transaksi Elektronik meliputi individu/orang per orang dan korporasi. Ini terbukti dari ketentuan pasal-pasal tersebut yang diawali dengan kata "Setiap orang ..." dan "koorporasi...". Menurut ketentuan Pasal 1 ayat (22) dan (23) Undang-undang ini, yang dimaksud dengan orang adalah Orang perseorangan, baik warga Negara Indonesia, Warga Negara Asing, maupun badan hukum. Dan Badan Usaha adalah Perusahaan perseorangan atau perusahaan per- sekutuan, baik yang berbadan hukum maupun yang tidak berbadan hukum.

Pembedaan secara jelas antara manusia dan badan hukum sebagai subyek tindak pidana adalah penting karena hal ini berkaitan erat dengan kesalahan, pertanggungjawaban pidana, mengenai sanksi pidana serta pelaksanaan pidana itu sendiri. Oleh Van Hantum ditegaskan pula “ bahwa sebaiknya pembentuk Undang-undang membuat ketentuan umum dalam hal suatu tindak pidana dilakukan oleh suatu korporasi ".

\section{c. Sistem Perumusan Sanksi Pidana, Jenis Sanksi, Lamanya Pidana Serta Pedoman Pemidanaan Dalam Undang-Undang Informasi Dan Transaksi Elektronik}

Sistem perumusan sanksi pidana dalam Undang-undang Informasi dan Transaksi Elektronik adalah alternatif kumulatif, menginggat bentuk perumusannya adalah “...dan/ atau...”.

1) Sistem Perumusan Jenis Sanksi Pidana Dalam Undang-Undang Informasi dan Transaksi Elektronik Jenis-jenis sanksi (strafsoort) pidana dalam Undang-undang Informasi dan Transaksi Elektronik yaitu pidana penjara dan denda.

2) Sistem Perumusan Lamanya Pidana Dalam Undang-Undang Informasi dan Transaksi Elektronik

${ }^{4}$ Op. Cit hal 63 
Perumusan lamanya pidana dalam Undang-undang Informasi dan Transaksi Elektronik adalah:

a) Maksimum khusus pidana penjara dalam Undang-undang Informasi dan Transaksi Elektronik paling lama 12 tahun dan paling sedikit tidak disebutkan;

b) Maksimum khusus pidana denda berkisar antara Rp 300.000.000,00 (tiga ratus juta rupiah), dan paling banyak Rp 12.000.000.000,00 (dua belas milyar rupiah).

\section{3) Pedoman Pemidanaan Dalam Undang-Undang Informasi Dan Transaksi Elektronik}

Undang-undang Informasi dan Transaksi Elektronik tidak mencantumkan pedoman pemidanaan, seyogyanya hal ini perlu menginggat sebagai berikut :

a) Dalam Undang-undang ini merumuskan korporasi sebagai subyek tindak pidana, tetapi pedoman pemidanaan terhadap pertanggungjawaban korporasi dirumuskan dalam penjelasan pasal, seharusnya terhadap pertanggungjawaban korporasi harus dirumuskan dalam pasal.

b) Dalam Undang-undang ini tidak dibuat pedoman ketika korporasi tidak membayar denda dan tidak pula membuat pedoman pidana pengganti denda terhadap korporasi.
Berdasarkan pembahasan diatas, maka dapat diketahui bahwa Undangundang Nomor 11 tahun 2008 tentang Informasi, dan Transaksi Elektronik dapat digunakan untuk menanggulangi jenis tindak pidana cyber child pornography (pornografi anak di internet) yang merupakan suatu fenomena/bentuk baru cyber crime secara umum.

\section{Undang-undang Nomor 44 tahun 2008 tentang Pornografi}

Istilah pornografi berasal dari bahasa Yunani, yaitu porne artinya pelacur, dan graphein artinya ungkapan. Secara etimologi, pornografi berarti suatu tulisan yang berkaitan dengan masalahmasalah pelacuran, dan tulisan itu kebanyakan berbentuk fiksi (cerita rekaan) yang materinya diambil dari fantasi seksual. ${ }^{6}$

Dalam Undang-undang Nomor 44 tahun 2008 tentang Pornografi dikatakan bahwa Pornografi adalah gambar, sketsa, ilustrasi, foto, tulisan, suara, bunyi, gambar bergerak, animasi, kartun, percakapan, gerak tubuh, atau bentuk pesan lainnya melalui berbagai bentuk media komunikasi dan/atau pertunjukan

\footnotetext{
${ }^{5}$ Alex A. Rachim, 1997, Pornografi dalam Pers, Sebuah Orientasi, Dewan Pers, Jakarta, hal 1011

6 I Made Bandem, 1995, Pornografi, Pornoaksi dan Kebebasan Berekspresi Dalam Seni (Tanggapan terhadap RUU Anti Pornografi dan Pornoaksi) Kaja and Kelod Balinese Dance in Transition. K.L.: Oxford University Press
} 
di muka umum, yang memuat kecabulan atau eksploitasi seksual yang melanggar norma kesusilaan dalam masyarakat.

\section{a. Sistem Perumusan Tindak Pidana Dalam Undang-Undang Pornografi}

Ketentuan pidana dalam Undangundang pornografi tercantum dalam Pasal 29 sampai dengan 38.

Berdasarkan Pasal-pasal tersebut diatas, unsur-unsur pasal pada tiap-tiap tindak pidana yaitu:

1) Pasal 29 jo Pasal 4 ayat (1) dengan unsur: memproduksi, membuat, memperbanyak, menggandakan, menyebarluaskan, menyiarkan, mengimpor, mengekspor, menawarkan, memperjualbelikan, menyewakan atau menyediakan pornografi yang memuat persenggaman, kekerasan seksual, masturbasi atau onani, ketelanjangan atau tam-pilan yang mengesankan ketelan-jangan, alat kelamin dan pornografi anak;

2) Pasal 30 jo Pasal 4 ayat (2) dengan unsur: menyajikan secara eksplisit ketelanjangan atau tampilan yang mengesankan ketelanjangan, menyajikan secara eksplisit alat kelamin, mengeksploitasi atau memamerkan aktivitas seksual dan menawarkan atau mengiklankan, baik langsung maupun tidak langsung layanan seksual;

3) Pasal 31 jo Pasal 5, dengan unsur: meminjamkan atau mengunduh pornografi;
4) Pasal 32 jo Pasal 6, dengan unsur: memperdengarkan, mempertontonkan, memanfaatkan, memiliki, atau menyimpan produk pornografi tanpak diberi kewenangan oleh undangundang;

5) Pasal 33 jo Pasal 7, dengan unsur: mendanai atau memfasilitasi;

6) Pasal 34 jo pasal 8, dengan unsur: dengan sengaja atau atas persetujuan dirinya menjadi objek atau model yang mengandung muatan pornografi;

7) Pasal 35 jo Pasal 9, dengan unsur: menjadikan orang lain sebagai objek atau model yang mengandung muatan pornografi;

8) Pasal 36 jo Pasal 10, dengan unsur: mempertontonkan diri atau orang lain dalam pertunjukan atau di muka umum yang menggambarkan ketelanjangan, eksploitasi seksual, persenggamaan, atau yang bermuatan pornografi lainnya;

9) Pasal 37 jo Pasal 11 : melibatkan anak dalam kegiatan dan/atau sebagai objek;

10) Pasal 38 jo Pasal 12, dengan unsur: mengajak, membujuk, memanfaatkan, membiarkan, menyalahgunakan kekuasaan atau memaksa anak dalam menggunakan produk atau jasa pornografi.

b. Sistem Perumusan Pertanggung jawaban Pidana Dalam Undangundang Pornografi

Pelaku tindak pidana atau yang dapat dimintakan pertanggung jawaban 
pidana dalam Undang-undang Pornografi adalah orang perorangan atau korporasi, baik berbadan hukum maupun tidak berbadan hukum. Ini terbukti dari ketentuan Pasal 3 yang menyebutkan Setiap orang adalah orang perseorangan atau korporasi, baik yang berbadan hukum maupun yang tidak berbadan hukum, itupun terlihat dari pasal-pasal dalam Undang-undang tersebut yang diawali dengan kata "setiap orang...." yang berarti merujuk pada orang dan atau badan hukum. Di samping itu dalam Pasal 1 ayat (2) disebutkan adanya jasa pornografi yang ternyata tidak ada penjelasannya mengenai apa yang dimaksud jasa pornografi. Sehingga dengan demikian maka jasa iklan cyber child pornografhy (pornografi anak di internet) yang banyak dijumpai di situssitus di internet dapat dikategorikan sebagai jasa pornografi yang bisa dilakukan baik oleh peorangan maupun korporasi (atau dalam hal ini bisa oleh Internet Service Providers/ISPs sebagai penyelenggara jasa pornografi.

Mengenai korporasi sebagai subyek tindak pidana terlihat pula dalam Undang-undang antara lain, Undangundang Nomor 5 tahun 1984 tentang Perindustrian, Undang-undang Nomor 5 tahun 1997 tentang Psikotropika, Undang-undang Nomor 23 tahun 1997 tentang Lingkungan Hidup, Undangundang Nomor 5 tahun 1999 tentang Larangan Praktek Monopoli dan
Persaingan tidak sehat, Undang-undang Nomor 8 tahun 1999 tentang Perlindungan Konsumen, Undang-undang Nomor 31 tahun 1999 Jo Undang-undang Nomor 20 tahun 2001 tentang Korupsi, Undang-undang No 15 tahun 2002 tentang Tindak Pidana Pencucian Uang, Undang-undang Nomor 30 tahun 2009 tentang Ketenagalistrikan, Undangundang Nomor 35 tahun 2009 tentang Narkotika, Undang-undang Nomor 45 tahun 2009 tentang Perikanan.

\section{c. B Sistem Perumusan Sanksi, Jenis Sanksi, Lamanya Pidana Serta Pedoman Pemidanaan Dalam Undang-Undang Pornografi}

Sistem perumusan sanksi pidana dalam Undang-undang Pornografi adalah alternatif kumulatif, menginggat bentuk perumusannya adalah “...dan/ atau...".

\section{1) Sistem Perumusan Jenis Sanksi Pidana Dalam Undang-Undang Pornografi}

Jenis-jenis saksi (strafsoort) pidana dalam Undang-undang Pornografi yaitu pidana penjara dan denda, serta pidana tambahan terhadap korporasi sebagaimana disebutkan dalam Pasal 41 berupa Pembekuan izin usaha, Pencabutan izin usaha, Perampasan kekayaan hasil tindak pidana dan Pencabutan status badan hukum.

Dalam hal tindak pidana pornografi yang dilakukan korporasi, selain pidana penjara dan denda terhadap 
pengurusnya, dijatuhkan pula pidana denda terhadap korporasi dengan ketentuan maksimum pidana dikalikan 3 (tiga) dari pidana denda yang ditentukan dalam setiap pasal. Hal demikian, sesuai dengan ketentuan Pasal 40 ayat (7).

\section{2) Sistem Perumusan Lamanya Pidana Dalam Undang-Undang Pornografi}

Perumusan lamanya pidana dalam Undang-undang Pornografi adalah:

1) Maksimum khusus pidana penjara berkisar antara 1 tahun - 15 tahun;

2) Maksimum khusus pidana denda berkisar antara Rp. 250.000.000.00 - Rp. 7.500.000.000,00.

Pidana denda yang dikenakan kepada korporasi apabila dinilai secara nominal, dengan maksimum khusus denda berkisar antara Rp. 250.000.000,00 (dua ratus lima puluh juta rupiah) sampai Rp. 7.500.000.000,00 (tujuh miliar lima ratus juta rupiah), jumlahnya sangat sedikit dibandingkan dengan keuntungan yang diperoleh dari hasil kejahatannya.

\section{3) Pedoman Pemidanaan Dalam Undang- undang Pornografi}

Dalam Undang-undang pornografi tidak ada pengaturan secara tegas dan jelas yang bersifat sebagai pedoman pemidanaan atau cara bagaimana pidana dilaksanakan (strafmodus), dalam hal:

a) Pidana denda tidak dibayar oleh korporasi;

b) Tidak ada pedoman pemidanaan bagi hakim dalam penjatuhan pidana, terutama jika muncul percobaan dan penyertaan dalam melanggar ketentuan diatas.

\section{Kitab Undang-Undang Hu-kum Pidana (KUHP)}

Didalam KUHP tidak ada rumusan Pasal yang menyebutkan secara jelas dan tegas tentang Pornografi. Masalah Pornografi dapat dikatagorikan sebagai kejahatan terhadap kesusilaan, pengaturannya ada dalam Ban XIV mulai Pasal 281 sampai dengan Pasal 303 bis,

\section{a. Sistem Perumusan Tindak Pidana Kesusilaan Dalam KUHP \\ Perumusan tindak pidana} kesusilaan dalam KUHP yang dapat digunakan terhadap tindak pidana cyber child pornography, terdapat pada pasalpasal sebagai berikut :

1) Pasal 282

Unsur-unsur tindak pidana dari Pasal 282 ayat (1), (2) dan (3), adalah sebagai berikut :

a) Menyiarkan;

b) Mempertunjukkan, atau menempelkan di muka umum tulisan, gambar atau benda, yang telah diketahui isinya melanggar kesusilaan;

c) Memasukkannya ke dalam negeri, meneruskannya, mengeluarkannya dari negeri atau 
d) Mempunyainya dalam persediaan;

e) Menjadikan hal tersebut diatas sebagai pencaharian atau kebiasaan.

Batasan gambaran atau benda yang isinya melanggar kesusilaan adalah sangat luas, karena tidak dijelaskan pengertian kesusilaan yang bagaimana menurut undang-undang. Undang-undang harus menyebutkan secara jelas batasan kesusilaan, karena hal ini untuk menghindari penafsiran yang berbedabeda dari setiap orang.

\section{Menurut Barda Nawawi Arief,} delik kesusilaan adalah delik yang berhubungan dengan (masalah) kesusilaan. Apabila dikaji lebih mendalam, ternyata tidaklah mudah untuk memberikan pengertian dan batasan "kesusilaan" cukup luas dan berbedabeda menurut pandangan dan nilai-nilai yang berlaku dalam masyarakat. Terlebih pada dasarnya setiap delik atau tindak pidana mengandung di dalamnya pelanggaran terhadap nilai-nilai kesusilaan.

\section{2) Pasal 283}

Dalam Pasal 283 ayat(1 dan2) disebutkan menyerahkan atau memperlihatkan tulisan, gambar atau benda yang melanggar kesusilaan. Dengan tanpak memberikan batasan atau pengertian yang jelas mengenai kesusilaan, sehingga dapat dikatakan sama dengan Pasal 282 artinya, bahwa pornografi

\footnotetext{
${ }^{7}$ Nyoman Serikat Putra Jaya, 2008, Beberapa Pemikiran Kearah Pengembangan Hukum Pidana, PT. Citra Aditya Bakti, Bandung, hal 25 28
}

merupakan hal yang bertentangan dengan pandangan masyarakat umumnya tentang kepatutan dan kesopanan.

Penyebarluasan gambar, tulis an atau benda yang melanggar kesusilaan tadi dilakukan dengan cara menawarkan atau memberikan untuk terus maupun untuk sementara waktu. Secara umum penyebarluasan gambar tadi dapat dilakukan dengan melalui beberapa cara, baik menggunakan media komunikasi, media cetak, media elektronik lainnya.

Dengan demikian untuk masalah cyber child pornography dapat digunakan Pasal 283 sebagai pasal yang dapat menjerat pelaku kejahatan.

3) Pasal 289

Rumusan Pasal 289 KUHP ini kurang tepat dikenakan tindak pidana cyber child pornography, karena :

a) Dalam rumusan Pasal 289 tidak menyebutkan secara jelas tentang cara melakukan penyebarluasan perbuatan yang melanggar kesusilaan dalam hal ini cyber child pornography. Cara apa yang digunakan untuk melakukan penyebarluasan perbuatan yang melanggar kesusilaan merupakan hal penting, karena ini berkaitan dengan media komunikasi yang digunakan. Dari beberapa kasus kejahatan internet, apabila pelaku dapat ditangkap oleh Polisi, akan digunakan hukum Negara dimana pelaku ditangkap. 
b) Pasal 289 ini menekankan pada mereka yang dengan kekerasan atau ancaman kekerasan memaksa seseorang untuk melakukan perbuatan cabul, diancam karena melakukan perbuatan yang menyerang kehormatan kesusilaan.

c) Dalam kaitannya dengan cyber child pornography, pasal ini dapat dikenakan pada mareka yang memaksa seseorang untuk melakukan perbuatan cabul. Yang dimaksud dengan seseorang disini tidaklah jelas, dapat orang dewasa maupun anak-anak. Jadi, digunakan untuk menanggkap orang dewasa yang menyuruh orang lain untuk melakukan perbuatan cabul tersebut.

4) Pasal 290

Pasal ini lebih tepat digunakan untuk menangkap pelaku Paedophilia yang bermunculan di internet. Para pelaku Paedophilian adalah para mereka yang memiliki kelainan atau penyimpangan seksual yaitu melakukan hubungan seksual dengan anak-anak. Masalah Paedophilian di internet juga merupakan suatu masalah penting sebagaimana halnya dengan cyber child pornography.

Pasal 290 dapat diterapkan untuk pelaku tindak pidana cyber child pornography untuk unsur: seseorang melakukan perbuatan cabul tadi dengan seseorang yang umumnya belum men- capai lima belas tahun atau belum waktunya untuk dikawin.

\section{b. Sistem Perumusan Pertang gung -} jawaban Pidana Dalam Tindak Pidana Kesusilaan di KUHP

Sistem perumusan pertang gungjawaban pidana dalam tindak pidana kesusilaan berhubungan dengan subyek tindak pidana kesusilaan, yaitu individu. Dalam KUHP, sistem pertanggungjawaban pidana berdasarkan pada asas kesalahan.

\section{c. Sistem Perumusan Sanksi, Jenis Sanksi, Lamanya Pidana Serta Pedoman Pemidanaan Terhadap Kejahatan Kesusilaan Dalam KUHP}

Sistem perumusan sanksi pidana mengenai kejahatan kesusilaan dalam KUHP adalah sistem alternatif dan perumusan pidana pokok secara tunggal.

Penggunaan sistem alternatif terdapat pada sebagian besar sistem perumsuan sanksi pidana dalam KUHP.

\section{1) Sistem Perumusan Jenis Sanksi Pidana Dalam Tindak Pidana Kesisilaan Dalam KUHP}

Perumusan jenis sanksi pidana (strafsoort) dalam tindak pidana kesusilaan dalam KUHP terdiri atas pidana penjara dan pidana denda.

2) Sistem Perumusan Lamanya Pidana Dalam Tindak Pidana Kesusilaan Dalam KUHP 
Lamanya pidana (strafmaat) pengaturan mengenai cyber child penjara dalam kejahatan kesusilaan pornography (pornografi anak di intenet) diancamkan bervariasi, mulai dari yang yaitu diatur dalam Bab VIII Bagian terendah 9 (Sembilan) bulan sampai dengan 9 (Sembilan) tahun. Untuk pidana denda paling rendah Rp. 300 (Tiga Ratus Rupiah) dan paling tinggi Rp. 3.000,00 (Tiga Ribu Rupiah).

Minimum umum menurut Pasal 12 ayat (2) KUHP untuk pidana penjara selama waktu tertentu paling pendek adalah satu hari dan paling lama lima belas tahun berturut-turut; ayat (4) menegaskan bahwa pidana penjara selama waktu tertentu sekali-kali tidak boleh lebih dua puluh tahun.

\section{3) Pedoman Pemidanaan Dalam KUHP}

Dalam Pasal 30 ayat (2) dan (3) KUHP mengenai pidana denda, disebutkan jika denda tidak dibayar, lalu diganti dengan kurungan; lamanya kurungan pengganti paling sedikit adalah satu hari dan paling lama enam bulan; kurungan pengganti sekali-kali tidak boleh lebih dari delapan bulan (Pasal 30 ayat (6)). KUHP mengatur dalam hal denda tidak dibayar dan diganti kurungan yang tidak boleh lebih dari delapan bulan.

\section{B. KEBIJAKAN FORMULASI TINDAK PIDANA CYBER CHILD PORNOGRAPHY DI MASA YANG AKAN DATANG \\ 1. Sistem Perumusan Tindak Pidana}

Dalam Konsep KUHP 2008,

Kelima Paragraf ketiga yaitu Pornografi Anak Melalui Komputer.

Selain cyber child pornografi, dalam Konsep KUHP 2008 terdapat juga Bab khusus tentang Pornografi yaitu Bab XVI tentang Tindak Pidana Kesusilaan. Dibagian Kedua Paragraf Pertama mulai dari Pasal 468-474

Apabila dicermati isi pasal-pasal tersebut, secara rinci sudah mencan tumkan Pornografi anak. Sebenarnya ketentuan Pornografi anak dalam Konsep KUHP 2008 ini sudah diatur sebelumnya dalam Konsep KUHP 2006.

Berdasar pasal-pasal tersebut diatas, unsur-unsur pasal pada tiap-tiap tindak pidana yaitu :

a. Pasal 468 ayat (1) dengan unsur pidananya : tulisan, suara atau rekaman suara, film atau yang dapat disamakan dengan film, syair lagu, puisi, gambar, foto, dan/ atau lukisan yang mengeks-ploitasi daya tarik seksual pada bagian tubuh, aktivitas seksual, hubungan seksual antara laki-laki dengan perempuan atau sesama jenis, atau aktivitas atau hubungan seksual dengan binatang, atau dengan jenazah;

b. Pasal 468 ayat (2) jo Pasal 468 ayat (1) dengan unsur pidananya : obyeknya anak;

c. Pasal 469 ayat (1) dengan unsur pidananya: menyiarkan, memper 
dengarkan, mempertontonkan, atau menempelkan tulisan, suara, atau rekaman suara, film atau yang dapat disamakan dengan film, syair lagu, puisi, gambar, foto, dan/atau lukisan melalui media massa cetak, media massa elektronik dan/atau alat komunikasi medio yang mengeksploitasi daya tarik seksual pada bagian tubuh, aktivitas seksual, hubungan seksual antara laki-laki dengan perempuan atau sesama jenis, atau aktivitas atau hubungan seksual dengan binatang atau dengan jenazah;

d. Pasal 469 ayat (2) jo Pasal 469 ayat (1) dengan unsur pidananya : obyeknya anak;

e. Pasal 470 dengan unsur pidanya menjadikan diri sendiri dan/atau orang lain sebagai model atau objek pembuatan tulisan, suara atau rekaman suara, film, atau yang dapat disamakan dengan film, syair lagu, puisi, gambar, foto, dan/atau lu-kisan yang mengeksploitasi daya tarik seksual pada bagian tubuh, aktivitas seksual, hubungan seksual antara laki-laki dengan perempuan atau sesama jenis, atau aktivitas atau hubungan seksual dengan binatang atau dengan jenazah;

f. Pasal 471 dengan unsur pidananya : memaksa anak-anak menjadi model atau objek pembuatan tulisan, suara atau rekaman suara, film, atau yang dapat disamakan dengan film, syair lagu, puisi, gambar, foto, dan/atau lukisan yang mengeksploitasi anak-anak untuk melakukan akti vitas seksual atau persetubuhan;

g. Pasal 472 dengan unsur pidananya : membuat, menyebarluaskan, dan menggunakan karya seni yang mengandung sifat pornografi di media masa cetak, media massa elektronik, atau alat komunikasi medio, dan yang berada di tempattempat umum yang bukan dimaksudkan sebagai tempat pertunjukan karya seni;

h. Pasal 473 dengan unsur pidananya : membeli barang pornografi dan/ atau jasa pornografi tanpa alasan yang dibenarkan;

i. Pasal 474 dengan unsur pidananya : mendanai atau menyediakan tem pat, peralatan dan/atau perleng kapan bagi orang lain untuk melakukan kegiatan pornografi dan/atau pameran pornografi.

Dalam rumusan pasal-pasal ter sebut diatas, tidak disebutkan mengenai unsur kesengajaan dan unsur sifat melawan hukum. Hal ini karena Konsep berpendirian bahwa:

a. Setiap tindak pidana selalu dianggap bertentangan dengan hukum, sehingga setiap tindak pidana selalu bersifat melawan hukum. Oleh karena itu dalam rumusan pasal tidak disebut "... bersifat melawan hukum... ".

b. Hanya tindak pidana yang 
dilakukan dengan sengaja saja yang dapat dikenai pidana. Apabila suatu tindak pidana karena kealpaan akan dikenai pidana, maka hal tersebut harus dinyatakan dengan tegas dalam Perundang-undangan. Hal ini ditegaskan dalam Pasal 39 ayat (1) dan (2) Konsep KUHP 2008.

Konsep KUHP tidak lagi membedakan antara "kejahatan kesu silaan" dengan "pelanggaran kesusilaan", sebagaimana ada dalam KUHP. Konsep hanya mengenal sebagai "tindak pidana kesusilaan". Penyusunan Konsep Buku II pada mulanya disusun oleh Tim Basaroedin (lebih dikenal dengan Konsep BAS), di mana Bab XVI Buku II masih diberi judul sama dengan KUHP yaitu "Kejahatan terhadap kesusilaan", karena memang masih berorientasi pada KUHP. Dalam perkembangan selanjutnya, Konsep BAS inilah yang digunakan serta mengalami pengeditan, perkembangan serta revisi. Dalam Konsep 1986/1987, judul Bab XVI Buku II sudah diubah menjadi "Tindak pidana Terhadap Kesusilaan", walaupun masih berorientasi pada "Kejahatan Kesusilaan" dalam KUHP dan Konsep BAS. Baru pada Konsep 1989/1990, 1991/1992, 1994, 1997/1998, 1999/2000 (Konsep KUM DANG), 2002-2004, 2005, 2006 sampai dengan Konsep terakhir 2008 dimasukkan pula "delik kesusilaan" yang berasal dari "pelanggaran kesusilaan" dalam Bab

\section{Buku III KUHP. ${ }^{8}$}

Dilihat dari berbagai KUHP asing, pengaturan tentang cyber child pornography (pornografi anak di internet) dikutip dari working document yang diselenggarakan oleh World Congress Against the Commercial Sexual Exploitation of Children:

a. Article 175 of the japanese penal code forbids the printed portrayal of adult genitals, intercourse and public hair. However, such presentation of children's genitalia is not stringently regulated. Further-more, Japanese commercial procedures have created ingenious ways to avoid prosecution or law enforcement intervention by creating sexually explicit materials which just barely avoid depcition of forbidden body parts.

b. In 1995, Taiwan passed a law criminalising the production, of paintings, video tapes, photo-graphs, CD-ROMs, "electronic signals ", and other products depicting indecent conduct or sexual interaction involving persons under 18 years of age.

c. The 1993 child protection law passed in the Philippines (Republic Act No. 7610) includes a provision which prohibits the employment or coercion of children under 18 years of age to perform in obscene publication or pornograpic materials. It also

\footnotetext{
${ }^{8}$ Op. Cit hal 255
} 
imposes sanctions on the sale or distribution of such materials.

d. Sri Lanka (Penal Code Sec. 286A) passed similar legislation in 1995 which protects children up to 18 years of age. In Cambodia, a draft proposal (Law on the Abolition of Child Trafficking and Prostituion, Art. 9A1, ii, iii) for a law against child exploitation includes a provision which prohibits the production, possesion, impor-tation, exportation or adver-tisement of drawings, paintings, writings, photographs, or films which depict persons under 18 years of age in an indecent, obscene, or derogatory manner. The draft law also contain a confiscatory provision (Art 9B).

e. In Australia, all States, and Teritories except New South Wals, have promulgated legislation which makes the mere possession of child pornography illegal. Legislation already existed which make possession for the purposes of distribution, sale or exhibition against the law. In 1995, The Australian Customs Service initiated a national intelligence project named Amigo enlisting the public in efforts to establish the nature and content of child pornography being trafficked in and out ofAustralia.

Di Eropa pengaturan tentang cyber child pornography (pornografi anak di internet) terlihat antara lain sebagai berikut :

a. In England and Wales, the law makes it a criminal offense to take, distribute , exhibit or possess even one "indecent" photograph of a child (Protection of Children Act 1978). The Law defines a child as a person under 16. The determination of "indecency" is a matter for the court.

b. In the Netherlands, the manufacture, dissemination, transport and export of pornography involving children under 16 is illegal (Criminal, Art. 240b, sec.1).In April 1995, the Code was amended to include stiffer sentences and to include sanctions for the mere possession of child pornography.

c. Norway's penal code was amended in 1992. The Section on child pornography applies directly to the introduction and possession of child pornography but not to the production of such. In order to prosecute for production of child porno-graphy, Norwegian prose-cutors resort to ohter sections of the penal code relating to inducing minors to sexual behaviour and contributing to acts of indecency.

d. Section $207 a$ of the Austrian Penal Code, passed in July 1994, imposes criminal sanctions for both commercial and amateur production and distribution of child pornography as well as for possession and/or acquisition of the same.

e. Germany also recently made 
possession of child pornography an offense under the German Penal Code.

f. France's Penal Code (Penal Code Art. 227-23) forbids fixing recording, or transmitting the pornographic image of a minor and the distribution of that images.

g. None of the Eastern European Countries, with the exception ofEstonia (Penal Code Art 200/3), however, have laws specifically directed at child pornography.

h. Many European Countries have very rigid mail secrecy laws and mail can be interfered with only under extraordinary circum-stances. Additionally, European postal authorities do not possess the police powers of US postal inspectors. Some countries have very strict penalties against sexual intercourse with a child, but very light sentece or fines for child pornography.

Di Amerika Utara pengaturan tentang cyber child pornography (pornografi anak di internet) terlihat antara lain sebagai berikut :

a. The US is widely considered to be a major consumer of child pornography, but it has also been among the most aggressive in dealing with perpetrators through the passage and enforcement of stirct child pornography laws. These laws (18 U.S.C.2251, 2251A, 2252, 2256) currently prohibit the production, receipt, distribution, possession, transportation , mailing and advertising of any "visual depiction" involving the use of child under 18 years of age irl sexually explicit conduct. Sexually explicit conduct inclu-des sexual acts as well as the "lascivious exhibition of the genitals or pubic area of any person. " A more recent law (18 U.S.C. 2285) makes it felony for any person outside U.S. territory to produce or traffic in child pornography with the intent that the materials be imported into the United States - an extraterritrorial application of U.S law to non - U.S. citizens.

b. Canada has a very comprehensive child pornography law.Section 163 of the Penal Code makes it a crime to import, produce, print or publish any child pornography which includes representations of children under 18 who are engaged in or who are depicted engaged in explicit sexual activity. Furthermore, mere possession of child pornography is also now prohibited in Canada.

Pengaturan Cyber Child Pornography (pornografi anak di internet) di Ameka Serikat adalah sebagai berikut :

18 USCS 2252 (1991) Sexual Exploitation of Children 2252 certain activities relating to material involving the sexual exploitation of minors any person who :

a. knowingly transports or ships in 
interstate or foreign commerce by any means including by computer or mails, any visual depiction, if

1) the producing of such visual depiction involves the use of a minor engaging in sexually explicit conduct, and

2) such visual depiction is of such conduct;

b. knowingly receives, or distributes any visual depiction that has been mailed, or has been shipped or transported in interstate or foreign commerce, or which contains materials which have been mailed or so shipped or transported, by any means including by computer, or knowingly reproduces any visual depiction for distribution in interstate or foreign commerce or through the mails, if

1) the producing of such visual depiction involves the use of a minor engaging in sexually explicit conduct, and

2) such visual depiction is of such conduct, shall be punished as provided in subsection (b) of this section.

c. Either

1) In the special maritime and teritorial jurisdiction of the United States, or on any land or building owned by, leased to, or otherwise used by or under the control of the Government of the United States, or in the Indian country as defined in section 1151 of this title, knowingly sells or. possesses with intent to sell any depiction, or

2) Knowingly sells or possesses with intent to sell any visual depiction that has been mailed, or has been shipped or transported in interstated or foreign commerce, or which was produced using materials which have been mailed or so shipped or transported, by any means, including by computer, if,

a) The producing of such visual depiction involves the use of a minor engaging, in sexually explicit conduct, and

b) Such visual depiction is of such conduct, or

(1) In the special maritime and territorial jurisdiction of the United States, or on any land or building owned by, leased to, or otherwise used by or under the control of the Government of the United States, or in the Indian country as defined in section 1151 of this title, knowingly possesses 3 or more books, magazines, periodicals, films, video tapes, or other matter which contain any visual depiction, or,

(2) Knowingly possesses 3 or more books, magazines, periodicals, films, video tapes, or other matter which contain any visual depiction that has been mailed, or has been shipped, or transported in interstate or 
foreign commerce, or which was produced using materials which have been mailed or so shipped or transported, by any means including by computer, if,

(a) The producing of suchvisual depiction involves the use of a minor engagingin sexually explicit conduct, and

(b) Such visaul depiction is such conduct, shall be punished as provided in subsection (b) of this section.

- Whoever violates paragraph (1), (2) or (3) of subsection (a) shall be fines under theis title or imprisoned not more than ten years, or both, but, if such person has aprior conviction under this chapter or chapter 109A, such person shall be fined under this title and imprisoned for not less than five years nor more than fifteen years.

- Whoever violates paragraph (4) of subsection (a) shall be fined under this title or imprisoned for not more than five years, or both.

2256 Definition for chapter for the purposes of this chapter (18 USCS 2251 et seq), the term:

a. "Minor" means any person under the 36 age of eighteen years,

b. "sexually explicit conduct" means actual or simulated-

1) sexual intercourse, including genital genital, oral-genital, analgenital, or oral-anal, whether bertween persons of the same or opposite sex,

2) bestiality,

3) masturbation,

4) sadistic or masochistic abuse (for the purpose of sexual stimulation), or

5) lascivious exhibition of the genitals or pubic area of any persons,

c. "producing" means producing, directing, manufacturing, issuing, publishing, or advertising,

d. "organization" means a person other than an individual,

e. "visual depiction" includes developed film and videotape,

$f$. "computer" has the meaning given that term in section 1030 of this title, and

g. "custody or control" includes temporary supervision over or responsibility for a minor whether legally or illegally obtained.

Dari berbagai Peraturan Perundangan Negara Asing di atas, ada beberapa hal yang secara umum sama, antara lain :

a. Kriminalisasi terhadap tindak pidana child pornography (pornografi anak). Langkah kriminalisasi ini dilakukan 
mulai dari tahap:

1) Production of paintings (memproduksi gambar);

2) Printed;

3) Products depicting indecent conduct or sexual interaction;

4) Possession;

5) Dissemination, distribution, publish;

6) To perform in obscene exhibitions or indecent shows whether live or video, or to model in obscene publication or pornographic materials, forbids the printed portrayal of adult genitals, intercourse and pubic hair.

b. Disebutkan media penyebarluasan, melalui video, photographs, $C D$ ROMS, "electronic signals";

c. Mengenai batasan usia anak memang berbeda pada tiap negara. Hal ini tidak menjadi masalah, karena secara umurn yang dimaksud anak adalah mereka yang berusia di bawah 18 tahun, ada juga yang menetapkan berusia di bawah 16 tahun.

d. Karena keterbatasan materi, sehingga tidak dapat diketahui berapa lama sanksi pidana yang dikenakan, jenis sanksi atau tindakan, pertanggungjawaban pidana pelaku.

\section{Sistem Perumusan Pertang- gungjawaban Pidana}

Pada pasal-pasal dari Konsep KUHP 2008 tersebut di atas, hanya menyebut "setiap orang", hal ini dapat dimengerti, bahwa pelaku tindak pidana kesusilaan adalah individu, bukan korporasi.

Untuk tindak pidana cyber child pornography (pornografi anak di internet), korporasi dapat ikut sebagai subyek hukum pidana, yaitu Internet Service Provider (ISP). Apabila pasalpasal tersebut di atas akan digunakan, seyogyanya rumusan subyek hukum pidana menjadi "barangsiapa...", dengan demikian, balk individu maupun korporasi dapat dikenai pidana.

Subyek hukum pidana dengan menyebutkan "barangsiapa... ", memberi arti yang lebih luas, terutama dalam hal jenis kejahatan transnasional, hal ini lebih bersifat antisipasi.

Pelaku tindak pidana cyber child pornography (pornografi anak di internet), pada umumnya adalah orang yang normal dan mampu bertanggungjawab, hanya saja ia memiliki penyimpangan seksual atau bahkan ia melakukan hal tersebut semata-mata untuk mencari keuntungan materiil belaka.

Konsep menganut prinsip pertanggungjawaban berdasarkan kesalahan (liability based on fault), penegasan mengenai hal ini terdapat pada Pasal 37 ayat (1) dan Pasal 39 ayat (1) Konsep. Walaupun demikian, Konsep memungkinkan adanya "pertanggungjawaban yang ketat " ("strict liability") dalam Pasal 38 ayat (1) dan "pertanggungjawaban pengganti" (vicarius liability) Pasal 38 ayat (2), 
3. Sistem Perumusan Sanksi, Jenis Sanksi, Lamanya Pidana Serta Pedoman Pemidanaan

Sistem perumusan sanksi pidana untuk pasal-pasal tersebut diatas, adalah :

a. Digunakan perumusan sistem pemidanaan yang bersifat pidana alternatif (Pasal 379, 468 ayat (1 dan 2));

b. Digunakan perumusan sistem pemidanaan yang besifat pidana komulatif (Pasal 470, 471, 472, 473 dan 474).

Jika berorientasi pada perkembangan jenis kejahatan melalui teknologi inforrnasi, dengan dapat dimasukkannya korporasi sebagai subyek hukum pidana, ancaman pidana serta sistem pemidanaan yang tercantum dalam pasal-pasal tersebut di atas, seyogyanya dikaji kembali.

\section{a. Sistem Perumusan Jenis Sanksi Pidana}

Sistem perumusan jenis pidana yang diancamkan adalah : pidana penjara dan pidana denda.

Apabila korporasi dijadikan sebagai subyek hukum pidana, sanksi pidana dapat berupa pidana pokok yang dijatuhkan secara kumulatif alternatif, yaitu pidana penjara serta pidana denda, serta dikenai tindakan yang berupa pencabutan hak-hak tertentu, perampasan barang-barang tertentu dan tagihan, pembayaran ganti kerugian.

\section{b. Sistem Perumusan Lamanya Pidana}

Perumusan lamanya pidana penjara untuk pasal-pasal tersebut diatas adalah :

1) minimum khusus : berkisar antara 1- 3 tahun;

2) maksimum khusus berkisar antara 7 - 15 tahun.

Ancaman pidana denda untuk pasal-pasal tersebut diatas adalah :

1) Maksimum khusus pidana denda berkisar antara kate-gori ke II Rp 7.500.000,00,- (Tujuh Juta Lima Ratus Ribu Rupiah);

2) Paling banyak kategori ke $\mathrm{V} R \mathrm{Rp}$ 300.000.000,00 (Tiga Ratus Juta Rupiah).

\section{c. Pedoman Pemidanaan}

Konsep berpegang pada "individualisasi pidana", yang memberi keleluasaan bagi hakim dalam memilih dan menentukan sanksi pidana apa yang tepat untuk pelaku tindak pidana, sehingga memerlukan adanya "fleksibilitas atau elastisitas pemidanaan" yang tetap dalam batas menurut undang-undang.

Bertolak dari pemikiran tersebut diatas, maka di dalam Konsep ditentukan hal-hal berikut :

1) sanksi yang tersedia dalam Konsep berupa "pidana" (yang terdiri dari "pidana pokok" dan "pidana tambahan") dan "tindakan". Namun, dalam penerapannya hakim dapat menjatuhkan berbagai alternatif sanksi sebagai berikut :

a) menjatuhkan "pidana pokok"

\footnotetext{
${ }^{9}$ Op. Cit hal 92-93
} 
saja;

b) menjatuhkan "pidana tambahan" saja;

c) menjatuhkan "pidana pokok" dan "pidana tambahan";

d) menjatuhkan "pidana pokok" dan "tindakan";

e) menjatuhkan "pidana pokok", "pidana tambahan" dan "tindakan".

2) Walaupun pada prinsipnya sanksi yang dapat dijatuhkan adalah pidana pokok yang tercantum dalam perumusan delik yang bersangkutan, namun hakim dapat juga menjatuhkan jenis sanksi lainnya, sepanjang dimung-kinkan/ diperbolehkan menurut aturan umum Buku 1.

Konsep tetap mempertahankan sistem atau pendekatan absolut (sistem maksimum) walaupun dengan beberapa modifikasi, yang bertolak dari prinsip keseimbangan mono-dualistik, yaitu memperhatikan keseimbangan kepentingan masyarakat dan kepentingan individu (pelaku).

\section{BAB IV}

KESIMPULAN DAN SARAN

\section{A. Kesimpulan}

Dari hasil dan pembahasan, dapatlah ditarik simpulan sebagai berikut :

1. Kebijakan formulasi hukum pidana yang ada di Indonesia saat ini dalam menanggulangi tindak pidana cyber child pornography (pornografi anak di internet) yang menjadi kajian khusus dalam tesis ini, secara umum dapat digunakan untuk mengatasi tindak pidana cyber child pornography (pornografi anak di internet), namun ada kekurangan dalam peraturan hukum positif tersebut, yaitu tidak adanya kualifikasi delik (Undang-undang Nomor 40 tahun 1999 tentang Pers, Undang-undang Nomor 23 tahun 2002 tentang Penyiaran, Undangundang Nomor 11 tahun 2008 tentang Informasi dan Transaksi Elektronik), korporasi dijadikan sebagai subyek tindak pidana tetapi tidak dibuat pedoman tentang pertang-gungjawaban korporasi apabila korporasi tidak membayar denda (Undang-undang Nomor 8 tahun 1992 tentang Perfilman, Undang-undang Nomor 36 tahun 1999 tentang Telekomunikasi, Undang-undang Nomor 23 tahun 2003 tentang Perlindu-ngan Anak, Undang-undang Nomor 23 tahun 2002 tentang Penyiaran, Undangundang Nomor 11 tahun 2008 tentang Informasi dan Transaksi Elektronik, Undang-undang Nomor 44 tahun 2008 tentang Pornografi).

2. Kebijakan hukum pidana yang akan datang dalam mengantisipasi tindak pidana cyber child pornography (pornografi anak di internet) masih dalam Konsep. Karena masih dalam Konsep, seyogyanya perlu dikaji kembali kebijakan kriminalisasi 
terhadap kejahatan di bidang lisasi ter-sebut, perlu dikaji hal-hal teknologi informasi secara umum berikut:

dan tindak pidana child porno-

1. Batas usia anak disebutkan secara graphy (pornograf anak) secara khusus. Ketentuan pasal yang berkaitan dengan tindak pidana cyber child pornography (pornografi anak di internet) dalam Konsep KUHP 2008 terdapat dalam Pasal 379 yang kriminalisasi dimulai dari memproduksi, menyediakan, mendistribusikan, membeli dan memiliki pornografi yang objeknya anak dibawah umur dengan mengunakan sistem komputer sebagai sarana untuk melakukan tindak pidana. Bila melihat ketentuan cyber child pornography (pornografi anak di internet) di berbagai negara, kebijakan legislatif dimulai dari tahap memiliki, ketentuan tersebut tidak terdapat dalam konsep KUHP 2008.

\section{B. Saran}

Kriminalisasi tindak pidana cyber child pornography (pornografi anak di internet) seyogyanya dialur secara tersendiri di luar KUHP. Dalam kriminategas;

2. Pertanggungjawaban pidana untuk korporasi;

3. Ancaman pidana dipisahkan secara tegas antara individu dengan korporasi;

4. Dicantumkannya kerjasarna internasional atau mutual legal assistance mengingat jenis kejahatan ini bersifat melintasi batas negara;

5. Berkaitan dengan persoalan tersebut, kebijakan hukum pidana di masa mendatang harus secara adaptif dapat digunakan untuk menampung nilai-nilai di Iingkungan Internasional, yang harus diadaptasikan dengan nilai-nilai Pancasila;

6. Harmonisasi secara eksternal dan internal serta melakukan perbandingan hukum pidana dengan beberapa negara, mutlak dilakukan dalam penyusunan suatu kebijakan hukum pidana, baik untuk kriminalisasi kejahatan cyber child pornography (pomografi anak di internet) maupun kriminalisasi kejahatan lain. 